\title{
Quantification of denitrification in permeable sediments: Insights from a two-dimensional simulation analysis and experimental data
}

\author{
Perran L. M. Cook, ${ }^{1 *}$ Frank Wenzhöfer, ${ }^{1,7}$ Søren Rysgaard, ${ }^{2}$ Oleksiy S. Galaktionov, ${ }^{3}$ Filip J. R. Meysman, ${ }^{3}$ Bradley D. \\ Eyre, ${ }^{4}$ Jeffrey Cornwell, ${ }^{5}$ Markus Huettel, ${ }^{6}$ Ronnie N. Glud ${ }^{7}$ \\ ${ }^{1}$ Max Planck Institute for Marine Microbiology, Celsiusstr 1. Bremen, 28359, Germany \\ ${ }^{2}$ Greenland Institute of Natural Resources, P.O. Box 570, DK 3900 Nuuk, Greenland \\ ${ }^{3}$ NIOO-KNAW, Centre for Estuarine and Marine Ecology, P.O. Box 140, 4400 AC Yerseke, The Netherlands \\ ${ }^{4}$ Centre for Coastal Biogeochemistry, Southern Cross University, P.O. Box 157 Lismore NSW 2480, Australia. \\ ${ }^{5}$ Horn Point Laboratory, 2020 Horns Point Rd, P.O. Box 775, Cambridge, MD 21613, USA \\ ${ }^{6}$ Department of Oceanography, Florida State University, Tallahassee, FL 32306-4320, USA \\ ${ }^{7}$ Institute of Biology, Marine Biological Laboratory, Strandpromenaden 5, 3000 Helsingør, Denmark
}

\begin{abstract}
Using a two-dimensional simulation analysis, we investigated the effects of sediment flushing on denitrification and the implications for two methods commonly used to measure denitrification in intact sediment cores: the $\mathrm{N}_{2}$ :Ar-ratio method and isotope pairing technique (IPT). Our simulations of experimental chamber incubations showed that advective flushing of the sediment can significantly increase sediment denitrification driven by $\mathrm{NO}_{3}{ }^{-}$from the water column (up to a factor of 5), but that nitrification and coupled nitrification-denitrification is reduced under conditions of sediment flushing (up to a factor of 6). $\mathrm{N}_{2}$ fluxes across SWI may differ significantly from actual rates of denitrification for periods lasting from $1 \mathrm{up}$ to more than $5 \mathrm{~d}$ after changes in parameters such as sediment flushing rate and water column $\mathrm{NO}_{3}{ }^{-}$concentrations. Simulations of the isotope pairing technique, showed that the rate of labeled $\mathrm{N}_{2}$ production, after the addition of ${ }^{15} \mathrm{NO}_{3}{ }^{-}$may take up to $\sim 24 \mathrm{~h}$ to reach steady state, depending on $\mathrm{NO}_{3}{ }^{-}$concentrations in the water column and sediment flushing rate. Measurements of denitrification in sand using IPT confirmed that short term incubations $(11 \mathrm{~h})$ underestimated the actual denitrification. Furthermore, model simulations were able to give a good estimate of measured $\mathrm{N}_{2}$ fluxes across SWI at different flushing rates under non-steady state conditions, confirming the ability of the model to realistically simulate experimental situations.
\end{abstract}

Denitrification is a key process in the nitrogen cycle because it represents a net loss of nitrogen from ecosystems. Consequently, the process has received much attention during the past 20 years. However, the vast majority of studies on denitrification have focused on muddy sediment, and relatively few have measured denitrification rates in sands (Eyre and Ferguson 2002; Lohse et al. 1996; Vance-Harris and Ingall 2005).

*Present address: CSIRO Land and Water 120 Meiers Rd, Indooroopilly 4068, Australia; e-mail:perran.cook@csiro.au

\section{Acknowledgments}

We thank Jack Middelburg, Bo Barker Jørgensen, Felix Janssen, Hans Røy, and Jan Fischer for fruitful discussions on this work. This work was supported by the EU-funded project COSA, contract EVK3-CT-2002-00076, the Netherlands Organisation for Scientific Research (PIONEER to Jack Middelburg), the Australian Research Council (Discovery Grant to Bradley Eyre DP0342956), and the Max Planck Society (through Antje Boetius and Bo Barker Jørgensen). The thoughtful comments of R. Jahnke, A. Rao, and an anonymous reviewer helped improve the manuscript.
Given that sandy sediments make up the majority of shelf sediments (Emery 1968), an accurate assessment of the rates and controlling factors of denitrification in such environments is vital for our understanding of $\mathrm{N}$ cycling in shelf areas.

A key difference between muddy and sandy sediments is that sandy sediments are permeable, which means that advective flow of pore water may contribute substantially to solute transport (Huettel et al. 2003). Flume experiments have shown that complex patterns of pore water exchange develop around ripples, resulting in a characteristic inflow of oxic overlying water at ripple troughs and an outflow of anoxic pore water at the ripple crests (Precht et al. 2004). Therefore, process rates in sands are only accurate and reliably addressed when the transport regime is properly accounted for (both in terms of patterns and flow rates). This is especially important for denitrification measurements, where the rate of $\mathrm{NO}_{3}{ }^{-}$transport into the anoxic sediment zone is an important factor determining the denitrification rate. Mimicking advective exchange processes 
during incubations is difficult. So far, this has only been taken into consideration by a limited number of investigations in flumes (Huettel et al. 1998; Precht et al. 2004) and benthic chambers (Glud et al. 1996; Huettel and Gust 1992; Janssen et al. 2005b). To date, no studies have investigated the effect of advective pore water flushing on benthic denitrification.

Denitrification rates in intact sediments are measured either by ex situ core incubations or in situ chamber incubations. In muddy sediments, these incubations are relatively straightforward, because only a gentle agitation of the water column is needed to obtain a realistic diffusive boundary layer thickness, e.g., Nielsen and Glud (1996). In sandy sediments, solute exchange is not mediated via a diffusive boundary layer, but by lateral pressure gradients causing bulk water exchange between the sediment and the overlying water (Webb and Theodor 1968). Within stirred chambers, such advective solute exchange is driven by radial pressure gradients over the sediment surface, the magnitude of which depends upon stirring speed and chamber geometry (Huettel and Gust 1992). Pressure-calibrated stirred chambers, which maintain a known pressure gradient over the sediment surface, permit measurements of denitrification in sandy sediments. Measured process rates can then be related to the flushing rate of the sediment, assuming no sediment topography within the chamber and homogeneous permeability within the sediment.

Measurements of denitrification are complicated by the high background of $\mathrm{N}_{2}$ in natural waters. Accordingly, one requires either high precision measuring techniques (potentially combined with lowering the $\mathrm{N}_{2}$ background), or alternatively, application of isotopic approaches. Two of the most widely used techniques to measure denitrification in coastal sediments are the isotope pairing technique (IPT) (Nielsen 1992) and the $\mathrm{N}_{2}$ :Ar method (Kana et al. 1994; Kana et al. 1998). A recent comparison between the $\mathrm{N}_{2}$ :Ar method and IPT in muddy sediments suggested that the two methods gave comparable results but that instrumental artefacts caused by $\mathrm{O}_{2}$ interference may lead to an overestimation of $\mathrm{N}_{2}$ production rates with the $\mathrm{N}_{2}$ :Ar method (Eyre et al. 2002). However, this effect may be instrument-specific (Eyre et al. 2002; Kana and Weiss 2004).

Effectively, each method suffers from its own set of advantages and disadvantages with European researchers tending to use IPT, whereas North American researchers seem to prefer the $\mathrm{N}_{2}$ :Ar ratio method (Eyre et al. 2002). The latter has the advantage that it directly measures gas fluxes, so no assumptions need to be made about the homogeneity of isotope distributions within the sediment. In addition, one does not have to decide on the nature of the $\mathrm{N}_{2}$ reduction that takes place (anammox or denitrification). The $\mathrm{N}_{2}$ :Ar method is, however, very sensitive to bubble formation during incubations, sampling, and storage (Eyre et al. 2002). Therefore, rate measurements are difficult in sediments with high rates of photosynthesis, and samples must be kept at ambient temperature and analyzed soon after sampling. Furthermore, direct
$\mathrm{N}_{2}$ flux methods may not reflect the current rate of denitrification taking place within the sediment, so great care should be taken to integrate the rates over relevant scales of time. Given the high temporal variability of advection and solute transport rates within permeable sediments (Precht and Huettel 2003), due consideration must be given when assessing denitrification rates. Changing solute transport regimes may affect the observed $\mathrm{N}_{2}$ fluxes.

Isotopic methods have the advantage of being relatively unaffected by bubble formation within cores or chambers, since a large fraction of the isotope reduced to $\mathrm{N}_{2}$ remains within the sediment over the typical timescale of incubations. Isotope samples can also be preserved reliably for long periods of time. Isotope pairing in combination with slurry techniques can also provide a useful means of distinguishing between anammox and denitrification activity (Risgaard Petersen et al. 2003). A further advantage of isotopes is that the production of labeled $\mathrm{N}_{2}$ gas unequivocally shows that denitrification is occurring, and no assumptions have to be made about fluxes across the sediment water interface (SWI) being in steady state with production rates. A disadvantage of IPT is that it requires the addition of ${ }^{15} \mathrm{NO}_{3}{ }^{-}$to the water column (preferably $>20 \%$ of the ${ }^{14} \mathrm{NO}_{3}{ }^{-}$concentration of the bottom water), which is assumed not to alter the natural rate of ${ }^{14} \mathrm{NO}_{3}{ }^{-}$denitrification. Model and experimental data both support this assumption (Middelburg et al. 1996; Risgaard Petersen et al. 1994), although it cannot be ruled out in all circumstances (for example, if $\mathrm{NO}_{3}{ }^{-}$addition were to significantly stimulate respiration). Because of the need to sample the water and the sediment for IPT, it is generally performed ex situ in small diameter cores. This has the potential to create biases in the measured rates compared to those occurring in situ. Note, however, IPT can also be applied in situ in benthic chambers (Nielsen and Glud 1996).

Of critical importance for the accuracy of IPT is that the added ${ }^{15} \mathrm{NO}_{3}{ }^{-}$tracer is flushed homogeneously into the denitrification zone, which may be questionable in some highly bioturbated sediments (A. Ferguson, unpubl. data). Although, we note Rysgaard et al. (1995) found no evidence for inhomogeneous tracer mixing in bioturbated sediments. In sandy sediments, the time taken for the tracer to reach and spread homogeneously within the denitrification zone will depend on the rate of transport of $\mathrm{NO}_{3}{ }^{-}$relative to the thickness of the sediment oxic and denitrification zones. The size of these two zones will, in turn, also depend on transport rates, consumption rates and concentrations of $\mathrm{NO}_{3}{ }^{-}$and $\mathrm{O}_{2}$ in the water column.

Biogeochemical reactive transport models allow us to test our understanding of sediment processes and predict how changing parameters affect processes, e.g., Berg et al. (2003). Such models have been used to evaluate IPT in sediments under diffusive conditions (Middelburg et al. 1996). To date, however, most biogeochemical models are one dimensional (vertical transport, horizontal biogeochemical layers), with diffusion as the dominant transport process. Solute transport 

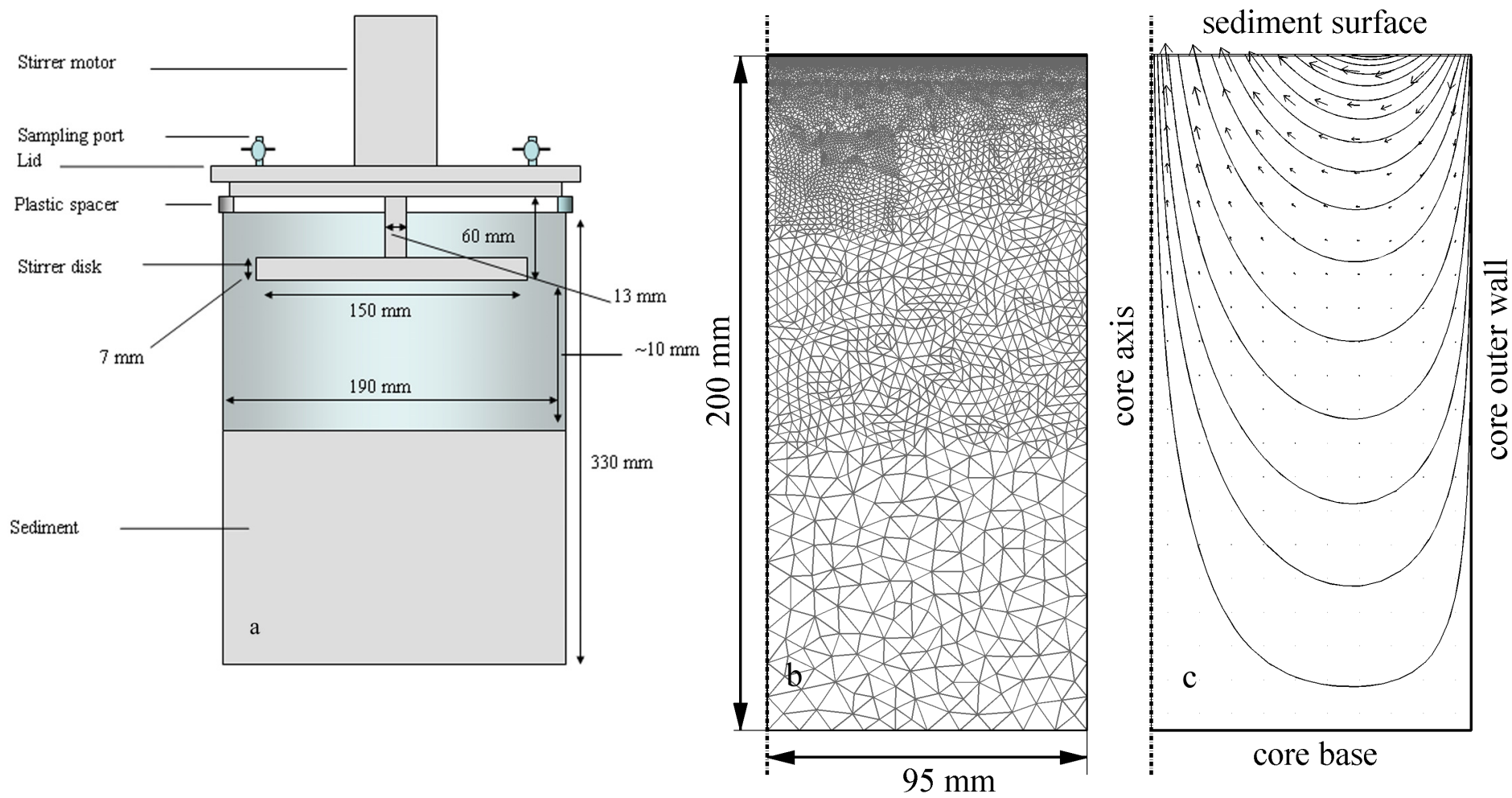

Fig. 1. (a) A diagram of the core set up during pre-incubations showing the lid suspended over the cores on plastic spacers. (b) The model subdomain used; representing an axial slice of a sediment core, showing the mesh applied. (c) The flow field (arrows) and streamlines induced within the sediment sub-domain of the model.

in permeable sediments mainly occurs through advection. This requires the characterization of the flow field in the pore water, which is typically multi-dimensional in nature, e.g., resulting from ripple topography (Huettel et al. 2003) or biologically induced burrow flushing (Meysman et al. 2005). The advent of more powerful computers and easy-to-use finite element modeling software now makes implementation of simple multi-dimensional transport reaction models possible (Meysman et al. 2006; Meysman et al. 2005).

Here we describe a biogeochemical model of $\mathrm{N}$ cycling incorporating advective porewater transport, which we use to theoretically assess the impact of advective transport on rates and measurements of denitrification. These model simulations are then compared to experimental data obtained from core incubations using both IPT and $\mathrm{N}_{2}$ :Ar method.

\section{Materials and Methods}

Biogeochemical model of $\mathrm{N}$-cycling-Following the approach of Meysman et al. (2006), two consecutive modeling steps were performed to quantify the impact of advective irrigation on sediment biogeochemistry. First, a flow model (FM) was constructed that simulates the three-dimensional (3D) flow pattern of pore water. Subsequently, the calculated pore water velocity field was incorporated into a reactive transport model, which simulated the concentration pattern of selected constituents. Both models were developed within the finite element modeling software package "FEMLAB 3.1" (www.comsol.com).

Model domain: The model domain represents the sediment within an incubation chamber (hereafter referred to as 'core' because the experiments were conducted ex situ) as described in Janssen et al. (2005a), that is, a core radius of $95 \mathrm{~mm}$ and a sediment depth of $200 \mathrm{~mm}$ (Fig. 1a). We assume a flat sediment surface, no heterogeneity in sediment parameters like porosity and permeability, and a perfect radial-symmetric stirring pattern in the overlying water. Under such "idealized" conditions, flow and concentration patterns will be radially symmetric. This way, the physically 3D model domain can be described mathematically by a two-dimensional (2D) model, which incorporates only two spatial variables (i.e., depth and distance from the central symmetry axis). A triangular unstructured mesh was used to discretize the model domain, with an element size of $\sim 100 \mu \mathrm{m}$ at the upper boundary (sediment surface), increasing to $10 \mathrm{~mm}$ at the lower boundary of the core (Fig. 1b).

Flow model: The steady-state flow pattern in permeable sediments is governed by two equations (see Meysman et al. 2005 for details). First, there is the continuity equation (Freeze and Cherry 1979).

$$
\nabla \cdot(\phi \rho \mathbf{v})=0
$$

where $\mathbf{v}$ is velocity in the pore water, $\nabla$ the gradient operator, $\phi$ the porosity, and $\rho$ the density of the pore water. Secondly, 
the constitutive relation between the velocity and the pressure is provided by Darcy's Law (Freeze and Cherry 1979),

$$
\mathbf{v}=-\frac{k}{\phi \eta}(\nabla p-\rho g \nabla z),
$$

where $k$ is the permeability, $\eta$ the fluid viscosity, $p$ the pressure, $g$ gravitational acceleration and $z$ represents the depth coordinate measured downwards from SWI. Under the condition that the pore water is incompressible, isothermal, and of uniform salinity, and assuming that porosity and permeability remain constant over the sediment domain, the substitution of Darcy's Law into the continuity equation leads to the classical Laplace equation (Meysman et al. 2005).

$$
\nabla^{2} p=0
$$

The solution of the Laplace equation (Eq. 3) requires appropriate boundary conditions. Along the bottom and lateral walls, we implemented a no-flux condition. At the sediment surface, we adopted the pressure relation,

$$
p(r, 0)=2 p_{0}\left(\frac{r^{2}}{r_{c}^{2}}-\frac{r^{4}}{2 r_{c}^{4}}\right),
$$

where $p_{0}$ is the pressure at the outer edge of the core with radius $r_{c}$. This relationship provided a good approximation for the pressure sensor data of Janssen et al. (2005a) measured at $40 \mathrm{rpm}\left(p_{0}=\sim 2\right)$. The magnitude of $p_{0}$ was modified for various stirring speeds by scaling it according to the relationship between pressure and stirring speed given by Janssen et al. (2005a). Together, Eqs. 3 and 4 produce the pressure distribution in the pore water from which one can subsequently calculate the associated velocity vector field by means of Eq. 2 (see Meysman et al. 2005 for details on this procedure). Fig. 1c shows the calculated flow field within the sediment model domain. For each flow simulation, we calculated the associated sediment flushing rates $\left(\mathrm{L} \mathrm{m}^{-2} \mathrm{~d}^{-1}\right)$ by integrating the vertical component of the simulated pore water velocity along the sediment surface and then dividing by the core area. The flushing rate suitably condenses the information in the flow field into a single parameter. To test the accuracy of the velocity field simulations, bromide incubations were carried out in the core set up. Simulated flushing rates agreed well with experimental values (P. Cook, unpubl. data). It should be noted that the flushing rate forms an integrated measure of the pore water flow field, and so, different flow fields may lead to the same flushing rate, depending on factors such as the permeability and geometry of the model domain. However, because the geometry and permeability are fixed in the present core set-up, the flushing rate becomes a suitable coordinate to plot our experimental results against, differentiating between stirring regimes in the overlying water.

Reactive transport model: Once the velocity field is computed from the FM, this quantity can be implemented in the mass conservation equation for a pore water constituent. For each solute $\left(\mathrm{O}_{2},{ }^{14} \mathrm{NO}_{3}{ }^{-},{ }^{15} \mathrm{NO}_{3},{ }^{28} \mathrm{~N}_{2},{ }^{29} \mathrm{~N}_{2},{ }^{30} \mathrm{~N}_{2}\right.$, and $\left.{ }^{14} \mathrm{NH}_{4}{ }^{+}\right)$, the applicable reactive transport equation is of the form (Boudreau 1997a; Meysman et al. 2006).

$$
\frac{\partial C_{i}}{\partial t}+\nabla \cdot\left(-D_{i} \cdot \nabla C_{i}+\mathbf{v} C_{i}\right)=R_{i}
$$

where $C_{i}(r, z)$ denotes the concentration, $D_{i}$ the effective diffusion coefficient, and $R_{i}$ the production rate due to chemical reactions. Because the porosity is assumed constant over the sediment domain, porosity terms do not appear in Eq. 5. The diffusion coefficient is corrected for tortuosity according to Boudreau (1996).

$$
D_{i}=[1-2 \ln \phi]^{-1} D_{i}^{m o l}
$$

where $D^{\text {nol }}$ represents the molecular diffusion coefficient, which is calculated as a function of temperature, $T$, and salinity, $S$, using the relations given by Boudreau (1997b). Note that in permeable sediments, the effective diffusion coefficient should normally also account for the effect of mechanical dispersion (Bear and Bachmat 1991; Meysman et al. 2006). However, mechanical dispersion is only important for sufficiently fast pore water flow. In all our simulations, grain scale Peclet numbers $P e=d_{50}\|\mathrm{v}\| / D_{i}^{m o l}$ (where $d_{\mathrm{EO}}$ is the median grain size) were considerably smaller than one, indicating that molecular diffusion dominated mechanical dispersion. Therefore, mechanical dispersion was not incorporated. As boundary conditions, we imposed a no-flux condition at the bottom and sides of the core, while at the sediment-water interface we imposed a fixed concentration.

The reaction rates in Eq. 5 are calculated from the reaction set, which includes four reactions: aerobic respiration, AR; denitrification, DN; ammonification, AM; and nitrification, NI.

$$
\begin{gathered}
\mathrm{AR}=\mathrm{CH}_{2} \mathrm{O}+\mathrm{O}_{2} \rightarrow \mathrm{CO}_{2}+\mathrm{H}_{2} \mathrm{O} \\
\mathrm{DN}=\mathrm{CH}_{2} \mathrm{O}+0.8 \mathrm{NO}_{3}^{-}+0.8 \mathrm{H}^{+} \rightarrow \mathrm{CO}_{2}+0.4 \mathrm{~N}_{2}+1.4 \mathrm{H}_{2} \mathrm{O} \\
\mathrm{AM}=\left\{\mathrm{NH}_{3}\right\}_{\mathrm{OM}}+\mathrm{H}^{+} \rightarrow \mathrm{NH}_{4}^{+} \\
\mathrm{NI}=\mathrm{NH}_{4}^{+}+2 \mathrm{O}_{2} \rightarrow \mathrm{NO}_{3}^{-}+\mathrm{H}_{2} \mathrm{O}+2 \mathrm{H}^{+}
\end{gathered}
$$

The rates of aerobic respiration and denitrification were modeled using the classical cascade formulation for electron acceptors (Berg et al. 2003; Boudreau 1997b; Meysman et al. 2003; Van Cappellen and Wang 1996).

$$
\begin{gathered}
R_{A R}=R_{\min } \frac{\left[\mathrm{O}_{2}\right]}{\left[\mathrm{O}_{2}\right]+K_{\mathrm{O}_{2}}^{\text {sat }}} \\
R_{D N}=R_{\min } \frac{K_{\mathrm{O}_{2}}}{\left[\mathrm{O}_{2}\right]+K_{\mathrm{O}_{2}}^{\text {inh }}} \frac{\left[\mathrm{NO}_{3}^{-}\right]}{\left[\mathrm{NO}_{3}^{-}\right]+K_{\mathrm{NO}_{3}^{-}}^{\mathrm{sat}}}
\end{gathered}
$$

The volumetric remineralization rate (expressed per unit volume of porewater) was varied as a function of sediment depth according to the expression

$$
R_{\min }=R_{\min (0)} e^{\frac{z^{2}}{\lambda^{2}}}
$$

$\mathrm{R}_{\min (0)}$ in Eq. 9 was set to $340 \mathrm{mmol} \mathrm{L}^{-1} \mathrm{~d}^{-1}$ based on the results of bag incubations (see Results), and $\lambda$ was set to $0.1 \mathrm{~m}$, 
Table 1. A summary of the parameters used to set up the model used to simulate denitrification in the sediment cores

\begin{tabular}{|c|c|c|c|}
\hline Name & Unit & Value & Description \\
\hline$K_{\mathrm{O}_{2}}^{\text {sat }}$ & $\mu \mathrm{mol} \mathrm{L}-1$ & 5 & Half saturation constant for $\mathrm{O}_{2}$ limitation of oxic mineralization \\
\hline$K_{N O_{3}^{-}}^{\text {sat }^{2}}$ & $\mu \mathrm{mol} \mathrm{L}-1$ & 30 & Half saturation constant for $\mathrm{NO}_{3}^{-}$limitation of denitrification \\
\hline$K_{O_{2}}^{i h^{3}}$ & $\mu \mathrm{mol} \mathrm{L} \mathrm{L}^{-1}$ & 5 & Half saturation constant for $\mathrm{O}_{2}$ inhibition of denitrification \\
\hline $\mathrm{k}_{\mathrm{NI}}$ & $\mu \mathrm{mol}^{-1} \mathrm{~L}^{-1} \mathrm{~d}^{-1}$ & 12.5 & Nitrification constant \\
\hline $\mathrm{R}_{\min (0)}$ & 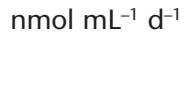 & 340 & $\begin{array}{l}\text { Maximum rate of aerobic organic matter oxidation and denitrification } \\
\text { (as } C \text { equivalents) }\end{array}$ \\
\hline$\gamma_{\mathrm{N}: \mathrm{C}}$ & & $1 / 15$ & Net production of $\mathrm{NH}_{4}{ }^{+}$in relation to $\mathrm{C}$ mineralized \\
\hline Perm & $\mathrm{m}^{2}$ & $2 \times 10^{-11}$ & Sediment permeability \\
\hline Porosity & & 0.35 & Sediment porosity \\
\hline
\end{tabular}

giving a depth-integrated to mineralization rate of $1250 \mu \mathrm{mol}$ $\mathrm{m}^{-2} \mathrm{~h}^{-1}$. The half-saturation constants in Eqs. 7 and 8 were set to $5 \mu \mathrm{mol} \mathrm{L} \mathrm{L}^{-1}$ and $30 \mu \mathrm{mol} \mathrm{L} \mathrm{L}^{-1}$, respectively, and the $\mathrm{O}_{2}$ inhibition constant for denitrification in Eq. 8 was also set to $5 \mu \mathrm{mol}$ $\mathrm{L}^{-1}$. The relative rates of ${ }^{14} \mathrm{NO}_{3}{ }^{-}$and ${ }^{15} \mathrm{NO}_{3}{ }^{-}$consumption were obtained by multiplying Eq. 8 with p and $(1-\mathrm{p})$ respectively, where $\mathrm{p}$ is the mole fraction of ${ }^{14} \mathrm{NO}_{3}{ }^{-}$in the total $\mathrm{NO}_{3}{ }^{-}$pool. Similarly, the relative production rates of ${ }^{28} \mathrm{~N}_{2},{ }^{29} \mathrm{~N}_{2}$, and ${ }^{30} \mathrm{~N}_{2}$ due to Eq. 8 were calculated using the respective factors $\mathrm{p}^{2}$, $2 \mathrm{p}(1-\mathrm{p})$, and $(1-\mathrm{p})^{2} . D_{14}$, the rate of denitrification measured using IPT was calculated according to Nielsen (1992):

$$
\begin{gathered}
D_{15}=P\left({ }^{29} N_{2}\right)+2 P\left({ }^{30} N_{2}\right) \\
D_{14}=D_{15} \frac{P\left({ }^{29} N_{2}\right)}{2 P\left({ }^{30} N_{2}\right)}
\end{gathered}
$$

where $D_{15}$ is the rate of ${ }^{15} \mathrm{NO}_{3}{ }^{-}$denitrification and $\mathrm{P}\left({ }^{29} \mathrm{~N}_{2}\right)$ and $\mathrm{P}\left({ }^{30} \mathrm{~N}_{2}\right)$ are the production rates of ${ }^{29} \mathrm{~N}_{2}$ and ${ }^{30} \mathrm{~N}_{2}$, respectively.

Organic carbon mineralization through other pathways such as sulfate and $\mathrm{Fe} / \mathrm{Mn}$ reduction were not modeled explicitly. However, the ammonium produced in these respiratory pathways was accounted for through the ammonification rate.

$$
R_{A M}=\gamma_{N C} R_{\min }
$$

The ratio $\gamma_{N C}$ of $\mathrm{NH}_{4}^{+}$produced to $\mathrm{C}$ mineralized was set to the value 1/15 based on previous observations of high C:N ratios of effluxes in nearshore sediments. Such high ratios are attributed to a high C:N ratio of the ambient organic matter (Cook et al. 2004). This resulted in a total sediment $\mathrm{NH}_{4}{ }^{+}$production rate of $83 \mu \mathrm{mol} \mathrm{m} \mathrm{m}^{-2} \mathrm{~h}^{-1}$, with a net efflux of $75 \mu \mathrm{mol} \mathrm{m} \mathrm{m}^{-2} \mathrm{~h}^{-1}$ at a sediment flushing rate of $3.5 \mathrm{~L} \mathrm{~m}^{-2} \mathrm{~d}^{-1}$. This compared well to the measured $\mathrm{NH}_{4}^{+}$efflux of 80 to $90 \mu \mathrm{mol} \mathrm{m}{ }^{-2} \mathrm{~h}^{-1}$ at a flushing rate of approximately $3.7 \mathrm{~L} \mathrm{~m}^{-2} \mathrm{~d}^{-1}$ in the core incubations. Finally, nitrification was modeled using bimolecular kinetics.

$$
R_{N I}=k_{N I}\left[O_{2}\right]\left[N H_{4}^{+}\right]
$$

where $k_{\mathrm{NI}}$ is the nitrification constant, which was set to 12.5 $\mu \mathrm{mol}^{-1} \mathrm{~L}^{-1} \mathrm{y}^{-1}$ compared to values of 5 to $29 \mu \mathrm{mol}^{-1} \mathrm{~L}^{-1} \mathrm{y}^{-1} \mathrm{com}-$ monly used in the literature, e.g., Berg et al. (2003); Soetaert et al. (1996); Wang and Van Cappellan (1996).
Our model assumed that no anammox took place, and this was indeed confirmed by slurry incubations (see Slurry incubations for anammox activity, this section). Furthermore, we assumed that pore water $\mathrm{O}_{2}$ was not significantly consumed due to reoxidation of reduced byproducts (e.g., $\mathrm{H}_{2} \mathrm{~S}, \mathrm{Fe}^{2+}$ ) that are produced "downstream" of the $\mathrm{O}_{2}$ and $\mathrm{NO}_{3}^{-}$zones. To assess the validity of this assumption, we performed some test model runs. Under advective flow conditions, such re-oxidation was indeed found to be negligible. A summary of all the key parameters used to construct the model is given in Table 1.

Denitrification simulations: Simulations were run to

(1) assess the impact of the advective transport regime (range of sediment flushing rates 3.5 to $87 \mathrm{~L} \mathrm{~m}^{-2} \mathrm{~d}^{-1}$ ) on steady state rates of denitrification and nitrification at different $\mathrm{NO}_{3}{ }^{-}$concentrations $\left(0,10,50\right.$, and $\left.250 \mu \mathrm{mol} \mathrm{L}{ }^{-1}\right)$ in the water column;

(2) assess the time-dependent response of sediment denitrification rates and $\mathrm{N}_{2}$ fluxes to the addition of $250 \mu \mathrm{mol} \mathrm{L} \mathrm{L}^{-1}$ $\mathrm{NO}_{3}{ }^{-}$to the water column following a steady state situation with no $\mathrm{NO}_{3}^{-}$in the water column. These simulations were run at two different transport regimes (flushing rate of 3.5 and $87 \mathrm{~L} \mathrm{~m}^{-2} \mathrm{~d}^{-1}$ );

(3) assess the time-dependent response of sediment denitrification rates and $\mathrm{N}_{2}$ fluxes to a stepwise decrease (from 87 to $3.5 \mathrm{~L} \mathrm{~m}^{-2} \mathrm{~d}^{-1}$ ) and a similar stepwise increase (from 3.5 to $87 \mathrm{~L} \mathrm{~m}^{-2} \mathrm{~d}^{-1}$ ) in the flushing rate. Steady state conditions were simulated at the initial flushing rate, before the sediment flushing rate was changed and the model run timedependently. The water column $\mathrm{NO}_{3}{ }^{-}$concentration was maintained at $10 \mu \mathrm{mol} \mathrm{L} \mathrm{L}^{-1}$ throughout these simulations;

(4) assess the time-dependent development of $D 14$ after the addition of $20 \mu \mathrm{mol} \mathrm{L}{ }^{-1}$ of ${ }^{15} \mathrm{NO}_{3}^{-}$to a core in steady state with a water column ${ }^{14} \mathrm{NO}_{3}{ }^{-}$concentration of 0,10 , and 50 $\mu \mathrm{mol} \mathrm{L}-1$ at a sediment flushing rate of $18 \mathrm{~L} \mathrm{~m}^{-2} \mathrm{~d}^{-1}$;

(5) assess the time-dependent development of $D 14$ at various sediment flushing rates (diffusive, 3.5, 18, 44, and $87 \mathrm{~L}$

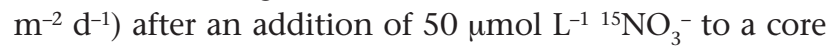
in steady state with a water column ${ }^{14} \mathrm{NO}_{3}{ }^{-}$concentration of $250 \mu \mathrm{mol} \mathrm{L}{ }^{-1}$;

6) assess the time-dependent development of $D 14$ with a 10 -fold increase in sediment respiration rates after an 
addition of $50 \mu \mathrm{mol} \mathrm{L}{ }^{-1}{ }^{15} \mathrm{NO}_{3}{ }^{-}$to a core in steady state with a water column ${ }^{14} \mathrm{NO}_{3}{ }^{-}$concentration of $250 \mu \mathrm{mol}$ $\mathrm{L}^{-1}$ and a sediment flushing rate of $18 \mathrm{~L} \mathrm{~m}^{-2} \mathrm{~d}^{-1}$;

(7) simulate denitrification, $\mathrm{N}_{2}$ fluxes and $D_{14}$ after the collection of cores from the field with an in situ ${ }^{14} \mathrm{NO}_{3}{ }^{-}$ concentration of $5 \mu \mathrm{mol} \mathrm{L}-1$ followed by incubation in a water bath containing $250 \mu \mathrm{mol} \mathrm{L}{ }^{-1}{ }^{14} \mathrm{NO}_{3}{ }^{-}$for $72 \mathrm{~h}$, before denitrification was measured using the $\mathrm{N}_{2}$ :Ar method and IPT (see Experimental section). Exact simulations of experimental data (see Experimental section) were not possible, particularly for $\mathrm{N}_{2}$ fluxes, because we did not know what the initial $\mathrm{N}_{2}$ distribution in the sediment was, nor did we know the exact in-situ flow field prior to core collection. Therefore, to simulate the denitrification rates in the cores, we assumed that the initial solute distributions $\left(\mathrm{O}_{2},{ }^{14} \mathrm{NO}_{3}{ }^{-}, \mathrm{NH}_{4}{ }^{+}\right.$, and $\mathrm{N}_{2}$ ) were in steady state at each flushing rate used and that the in-situ ${ }^{14} \mathrm{NO}_{3}{ }^{-}$concentration was $5 \mu \mathrm{mol} \mathrm{L}{ }^{-1}$. The concentration of ${ }^{14} \mathrm{NO}_{3}{ }^{-}$was then increased to $250 \mu \mathrm{mol} \mathrm{L} \mathrm{L}^{-1}$, and the model run time-dependently for $72 \mathrm{~h}$ to simulate the cores being placed in the high $\mathrm{NO}_{3}{ }^{-}$water bath before incubations commenced. In this simplified simulation, we also neglected any $\mathrm{N}_{2}$ fluxes due to solubility changes of $\mathrm{N}_{2}$ when the cores were warmed from $8^{\circ}$ to $15^{\circ}$ in the laboratory. We believe this is justified because the use of $\mathrm{N}_{2}$ :Ar ratios to calculate fluxes means that solubility changes will have a minor impact on the measured fluxes of $\mathrm{N}_{2}$. This was confirmed by the fact that the killed control cores only had a very low flux of $\mathrm{N}_{2}$ out of the sediment (see Results). After the simulated $72 \mathrm{~h}$ pre-incubation, the $\mathrm{N}_{2}$ flux across SWI, as well as the sediment denitrification rate were extracted from the model, simulating the $\mathrm{N}_{2}$ flux measurements at the commencement of the incubation. At this point, IPT measurements were simulated by adding the species ${ }^{15} \mathrm{NO}_{3}{ }^{-}$ to the overlying water, and a further time-dependent simulation run to follow the development of $D_{14}$.

Experimental-The study site from which all samples were collected was a shallow sandy site next to the Marine Biological Laboratory in Helsingør, Denmark. Permeability at the study site was measured using a constant head permeameter on 3 intact sediment cores (inner diameter $36 \mathrm{~mm}$ ) and amounted to an average value of $2 \pm 0.3 \times 10^{-11} \mathrm{~m}^{2}$ calculated according to Klute and Dirksen (1986). Sediment porosity was measured as described by Dalsgaard et al. (2000) on intact sediment cores taken from the study site and had an average value of 0.35 . Intact sediment cores for incubation experiments were taken manually in November 2003 at a water depth of $\sim 1 \mathrm{~m}$ and in situ temperature $8.5^{\circ} \mathrm{C}$, using core liners (inner diameter 190 $\mathrm{mm})$. After coring, a base was placed on the cores, and they were immediately returned to the laboratory, where they were submerged in a water bath at $15^{\circ} \mathrm{C}$ with $\mathrm{NO}_{3}{ }^{-}$concentrations of $\sim 250 \mu \mathrm{mol} \mathrm{L}{ }^{-1}$, compared to the in situ concentration of $\sim 5$ $\mu \mathrm{mol} \mathrm{L} \mathrm{L}^{-}$at that time of the year. While this may have significantly altered metabolic rates and the relative activity of different microbial communities, we do not consider this a problem here because our aim was to compare methods and not measure in-situ activities. Lids with stirrer disks (150 mm diameter) as described by Janssen et al. (2005a) were suspended over the cores on plastic spacers. This way, there was a $\sim \mathrm{cm}$ gap between the core and the lid, allowing a free exchange of water between the bath and the core (Fig. 1a). The distance between the sediment and the stirrer disk was $\sim 100 \mathrm{~mm}$, and the disk stirring speed set to that used in the final incubation. The following sets of experiments were conducted.

\section{Core incubations}

Control cores: Three cores were submerged in a water bath and $\mathrm{ZnCl}_{2}$ was added to a final concentration of $1 \%$. The cores were then pre-incubated with the lids suspended over the cores, at a stirrer disk speed of $40 \mathrm{rpm}\left(\sim 18 \mathrm{~L} \mathrm{~m}^{-2} \mathrm{~d}^{-1}\right)$ and left for $72 \mathrm{~h}$ before the lids were sealed and triplicate samples collected for $\mathrm{N}_{2}$ :Ar ratio determination over the 11-h incubation.

The impact of changing flow field: Eight cores had their stirrer speeds adjusted to 20, 40, 60, and $80 \mathrm{rpm}$ in duplicate, resulting in flushing rates of $\sim 3.7$ to $\sim 96 \mathrm{~L} \mathrm{~m}^{-2} \mathrm{~d}^{-1}$ calculated as described in the Flow model section. The cores were then left for $72 \mathrm{~h}$ with the lids open before they were sealed and samples taken over an $\sim 11$ - $\mathrm{h}$ period for $\mathrm{N}_{2}$ :Ar ratios, $\mathrm{NH}_{4}^{+}, \mathrm{NO}_{3}^{-}$, and $\mathrm{O}_{2}$. Over this $\sim 11$-h period, the $\mathrm{O}_{2}$ concentration dropped by $\sim 20 \%$ in the cores. After sampling, the lids were opened and suspended above the cores overnight. The following day, ${ }^{15} \mathrm{NO}_{3}{ }^{-}$was added to a final concentration of $\sim 50 \mu \mathrm{mol} \mathrm{L}{ }^{-1}$, and the lids were sealed. After an 11-h incubation period, the cores were opened and processed as described below.

IPT time series: Six cores had their stirrer speed adjusted to $40 \mathrm{rpm}$ (a flushing rate of $\sim 18 \mathrm{~L} \mathrm{~m}^{-2} \mathrm{~d}^{-1}$ ) and were allowed to equilibrate for $72 \mathrm{~h}$ with open, suspended lids. Experiments

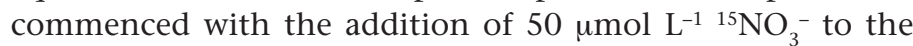
cores and the lids were sealed. The cores were then killed as described below in a time series, every $\sim 2 \mathrm{~h}$, up to $11 \mathrm{~h}$.

Slurry incubations for anammox activity - Rates of anammox were measured using the methods described by Rysgaard et al. (2004). The rates were found to be negligible and are not presented.

Bag incubations - Würgler-bag incubations were performed to compare the $\mathrm{N}_{2}$ :Ar and IPT methods in homogenized, anoxic sediment without nitrification and advective solute transport. Sediment was collected from the upper $5 \mathrm{~cm}$ horizon, homogenized, and divided into 6 Würgler bags each containing $200 \mathrm{~mL}$ sediment and $750 \mathrm{~mL}$ of site water. The bags were closed and pre-incubated for $7 \mathrm{~d}$ ensuring complete anoxia before incubations commenced. Organic matter $(0.1 \mathrm{~g}$ ground, dried Spirulina) and ${ }^{15} \mathrm{NO}_{3}{ }^{-}$were then added to the bags as summarized in Table 2. A control bag with $1 \%(\mathrm{w} / \mathrm{v})$ $\mathrm{ZnCl}_{2}$ was included. The bags were then inverted several times to ensure the ${ }^{15} \mathrm{NO}_{3}{ }^{-}$and organic matter were well mixed and 
Table 2. Summary of the treatments used for anoxic bag incubations of sediment from the study site

\begin{tabular}{ll}
\hline Bag & \multicolumn{1}{c}{ Treatment } \\
\hline 1 & $20 \mu \mathrm{mol} \mathrm{L}^{-1} 15 \mathrm{NO}_{3}^{-}$ \\
2 & $50 \mu \mathrm{mol} \mathrm{L}{ }^{-1}{ }^{15} \mathrm{NO}_{3}^{-}$ \\
3 & $100 \mu \mathrm{mol} \mathrm{L}^{-1} 15 \mathrm{NO}_{3}^{-}$ \\
4 & $20 \mu \mathrm{mol} \mathrm{L}^{-1}{ }^{15} \mathrm{NO}_{3}^{-}+0.1 \mathrm{~g} \mathrm{bag}^{-1}$ Spirulina \\
5 & $100 \mu \mathrm{mol} \mathrm{L}^{-1} 15 \mathrm{NO}_{3}^{-}+0.1 \mathrm{~g} \mathrm{bag}^{-1}$ Spirulina \\
6 & $1 \%(\mathrm{w} / \mathrm{v}) \mathrm{ZnCl}_{2}$ \\
\hline
\end{tabular}

placed on a shaker table throughout the incubation. The bags were sampled periodically by allowing the overlying water in the bags to drain directly into gas tight vials for $\mathrm{N}_{2}$ :Ar ratio and labeled $\mathrm{N}_{2}$ analysis as described below.

\section{Sampling and analysis}

Isotopes: $\mathrm{ZnCl}_{2}$ was added to the overlying water in the cores to a final concentration of $1 \%(\mathrm{w} / \mathrm{v})$, and the sediment was gently mixed with the water column. After the sediment had settled ( 1 min), a sub-sample of the overlying water was collected for $\mathrm{N}_{2}$ isotope analysis by a gas-tight syringe and transferred to a 12-mL gas-tight vial (Exetainer, Labco), where it was preserved with $1 \%(\mathrm{w} / \mathrm{v}) \mathrm{ZnCl}_{2}$. Samples were analyzed for the relative abundance of ${ }^{14} \mathrm{~N}^{15} \mathrm{~N}$ and ${ }^{15} \mathrm{~N}^{15} \mathrm{~N}$ on a gas chromatograph coupled to a triple-collector isotope-ratio mass spectrometer (RoboPrep G + in line with TraceMass, Europa Scientific) as described by Risgaard Petersen and Rysgaard (1995)

$\mathrm{N}_{2}$ :Ar samples: Samples for $\mathrm{N}_{2}$ :Ar ratio analysis were taken in duplicate or triplicate and were sampled directly through taps in the core liners (or plastic bags) using glass syringes, while replacement water from the bath was allowed to flow into the core through a second tap. The samples were then dispensed into 7-mL glass vials through a gas-tight tube, which was submerged below the surface of the liquid being dispensed until overflowing. The samples were then killed with $10 \mu \mathrm{L}$ saturated $\mathrm{HgCl}_{2}$, and the vials sealed with ground glass stoppers and submerged in a water bath at $15^{\circ} \mathrm{C}$. Samples were sent to laboratories at Southern Cross University, Australia (SCU), and the Horn Point Laboratories, U.S.A. (HPL). Samples at HPL were analyzed using a membrane inlet mass spectrometer (MIMS) as described by Kana et al. (1994). Samples at SCU were analyzed using a modified MIMS system with a reduction furnace to remove $\mathrm{O}_{2}$ as described by Eyre et al. (2002).

Miscellaneous: $\mathrm{O}_{2}$ samples were taken in the same manner as described above for $\mathrm{N}_{2}$ :Ar samples and then dispensed until overflowing into $12 \mathrm{~mL}$ Exetainers, to which Winkler reagents 1 and 2 were then added. Samples were then determined by Winkler titration as described by Grasshoff (1983). Samples for $\mathrm{NH}_{4}{ }^{+}$and $\mathrm{NO}_{3}{ }^{-}$analysis were frozen in plastic containers and determined with a Scalar Continuous-Flow-Autoanalyzer using the chemistry described by Grasshoff (1983).

All reported fluxes were derived from linear regression of solute concentrations (corrected for the addition of replace-

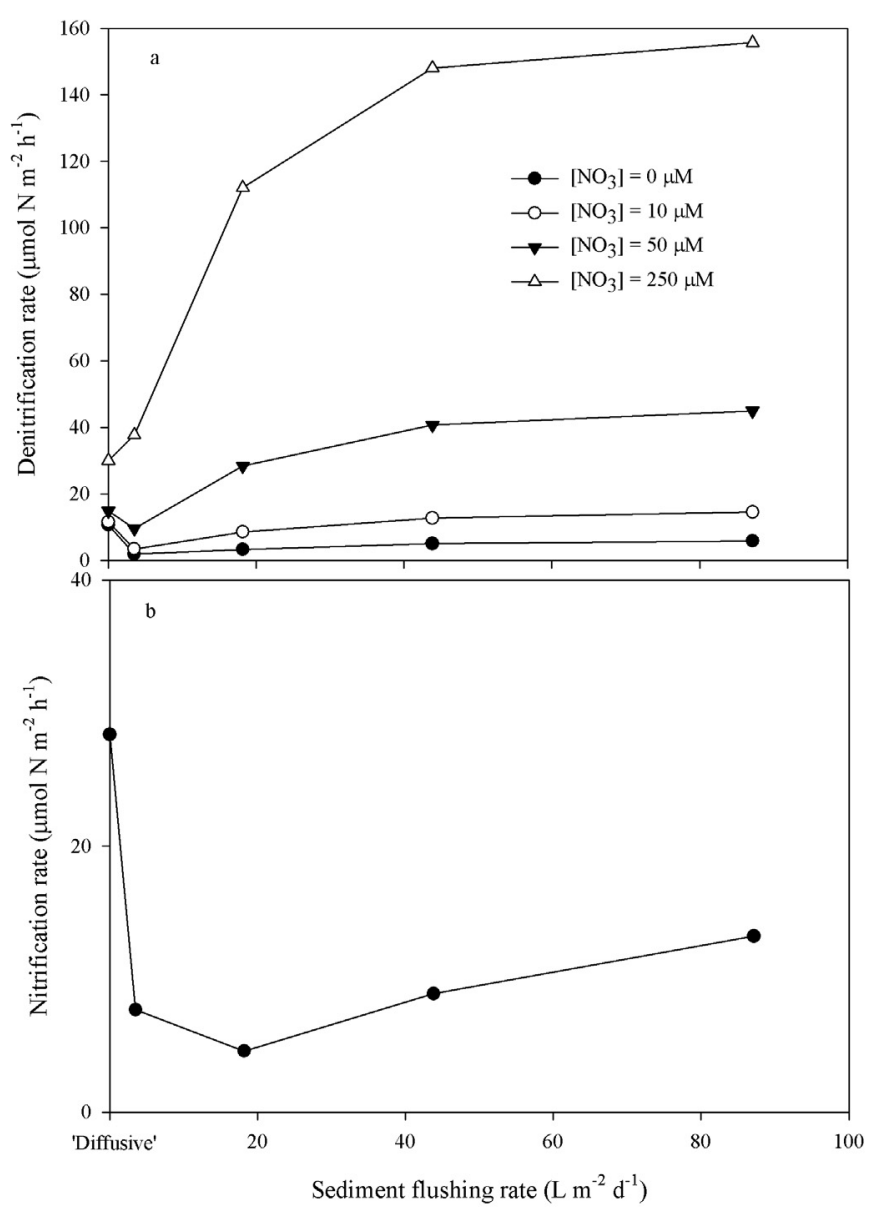

Fig. 2. The simulated effect of sediment flushing rate on (a) the steady state denitrification rate at water column $\mathrm{NO}_{3}{ }^{-}$concentrations of 0,10 , 50 , and $250 \mu \mathrm{mol} \mathrm{L}^{-1}$ and (b) the steady state nitrification rate. 'Diffusive' denotes simulations performed with no sediment flushing.

ment water) versus time ( $n=3$ to 5 data points) as described by Dalsgaard et al. (2000). Denitrification rates using IPT $\left(D_{14}\right)$ were calculated using the isotope pairing equations of Nielsen (1992), given in Eqs. 10 and 11.

\section{Results}

Effect of sediment flushing rate on steady state denitrification rates-Simulated steady state denitrification rates ranged from $2 \mu \mathrm{mol} \mathrm{m} \mathrm{m}^{-2} \mathrm{~h}^{-1}$ at a flushing rate of $3.5 \mathrm{~L} \mathrm{~m}^{-2} \mathrm{~d}^{-1}$ when no $\mathrm{NO}_{3}^{-}$ was present in the water column up to a denitrification rate of $156 \mu \mathrm{mol} \mathrm{m} \mathrm{m}^{-2} \mathrm{~h}^{-1}$ at a flushing rate of $87 \mathrm{~L} \mathrm{~m}^{-2} \mathrm{~d}^{-1}$ when $250 \mu \mathrm{mol}$ $\mathrm{L}^{-1}$ of $\mathrm{NO}_{3}^{-}$was present in the water column (Fig. 2a). Increasing the sediment flushing rate from 3.5 up to $87 \mathrm{~L} \mathrm{~m}^{-2} \mathrm{~d}^{-1}$ consistently increased the modeled rates of denitrification by a factor of $\sim 3$ to 5 for water column $\mathrm{NO}_{3}{ }^{-}$concentrations ranging from 0 to $250 \mu \mathrm{mol} \mathrm{L}{ }^{-1}$. Nitrification rates were highest under diffusive conditions, dropping by a factor of $\sim 2$ to 6 under flushed conditions, with minimum nitrification rates being observed at a flushing rate of $18 \mathrm{~L} \mathrm{~m}^{-2} \mathrm{~d}^{-1}$ (Fig. 2b). As such, the rates of denitrification fed by nitrification (coupled denitrification) were much greater 


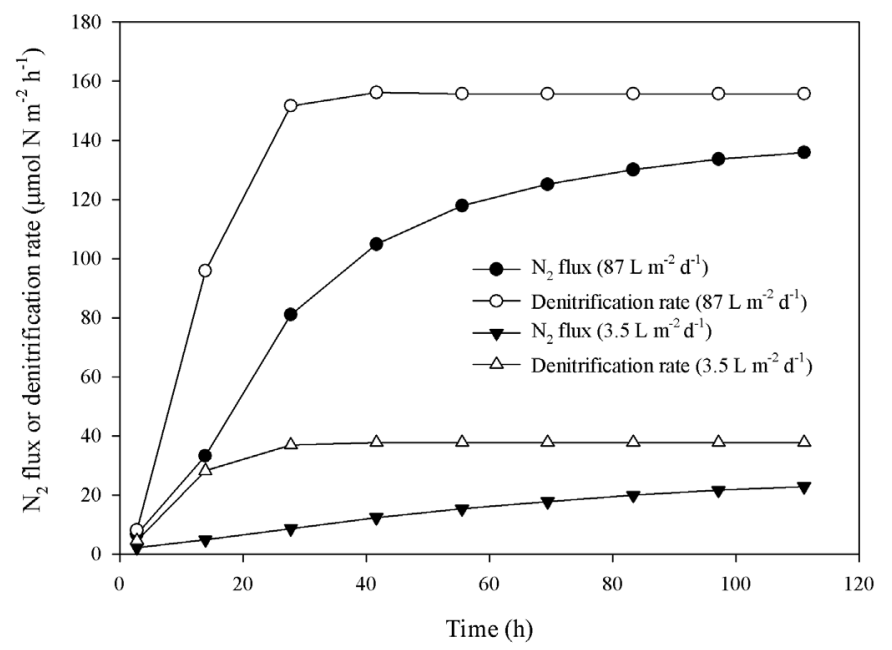

Fig. 3. The simulated time-dependent response of sediment denitrification rate and $\mathrm{N}_{2}$ flux out of the sediment after addition of $250 \mu \mathrm{mol} \mathrm{L} \mathrm{L}^{-1}$ $\mathrm{NO}_{3}{ }^{-}$to the water column of cores (at $\mathrm{t}=0$ ) run at a sediment flushing rate of 87 and $3.5 \mathrm{~L} \mathrm{~m}^{-2} \mathrm{~d}^{-1}$ with an initial $\mathrm{NO}_{3}{ }^{-}$concentration of $0 \mu \mathrm{mol} \mathrm{L}^{-1}$.

under diffusive conditions than flushed conditions. This resulted in higher denitrification rates under diffusive conditions when the $\mathrm{NO}_{3}{ }^{-}$concentration in the water column was $10 \mu \mathrm{M}$ or below.

Effect of changed conditions on net $N_{2}$ fluxes-A simulated addition of $250 \mu \mathrm{mol} \mathrm{L} \mathrm{L}^{-1} \mathrm{NO}_{3}^{-}$to a core previously at steady state with no $\mathrm{NO}_{3}^{-}$in the water column resulted in increased denitrification rates, which took $\sim 24 \mathrm{~h}$ to approach steady state at sediment flushing rates of both 3.5 and $87 \mathrm{~L} \mathrm{~m}^{-2} \mathrm{~d}^{-1}$ (Fig. 3). The $\mathrm{N}_{2}$ fluxes across SWI, however, responded much more slowly to the $\mathrm{NO}_{3}{ }^{-}$addition, with steady state rates still not reached after $111 \mathrm{~h}(4.6 \mathrm{~d})$.

Changing the sediment flushing regime had a marked transient impact on both the rates of denitrification within the sediment and the flux of $\mathrm{N}_{2}$ across SWI (Fig. 4). Increasing the flushing rate from a steady state condition of $3.5 \mathrm{~L} \mathrm{~m}^{-2} \mathrm{~d}^{-1}$ up to $87 \mathrm{~L} \mathrm{~m}^{-2} \mathrm{~d}^{-1}$, resulted in a large spike in the flux of $\mathrm{N}_{2}$ across SWI as $\mathrm{N}_{2}$ previously at steady state within the sediment was washed out by the increased flushing rates. Denitrification rates within the sediment showed a concurrent drop as oxic water was flushed into the sediment, inhibiting denitrification. Reducing the sediment flushing rate from 87 to $3.5 \mathrm{~L} \mathrm{~m}^{-2} \mathrm{~d}^{-1}$ had the opposite effect, with the flux of $\mathrm{N}_{2}$ across SWI showing an immediate drop, corresponding to lower transport rates of $\mathrm{N}_{2}$ across SWI. Sediment denitrification rates showed a transient jump, as reduced rates of $\mathrm{O}_{2}$ transport decreased $\mathrm{O}_{2}$ penetration into the sediment. This resulted in the denitrification of the large $\mathrm{NO}_{3}{ }^{-}$pool present in the formerly oxic region of the sediment. In both scenarios, the denitrification rates within the sediment and flux of $\mathrm{N}_{2}$ across SWI approached steady state within $24 \mathrm{~h}$ of the change in flushing regime, with the exception of the $\mathrm{N}_{2}$ flux after the flushing rate had been reduced. In this instance, the $\mathrm{N}_{2}$ flux was still well below the sediment denitrification rate even after $4 \mathrm{~d}$.

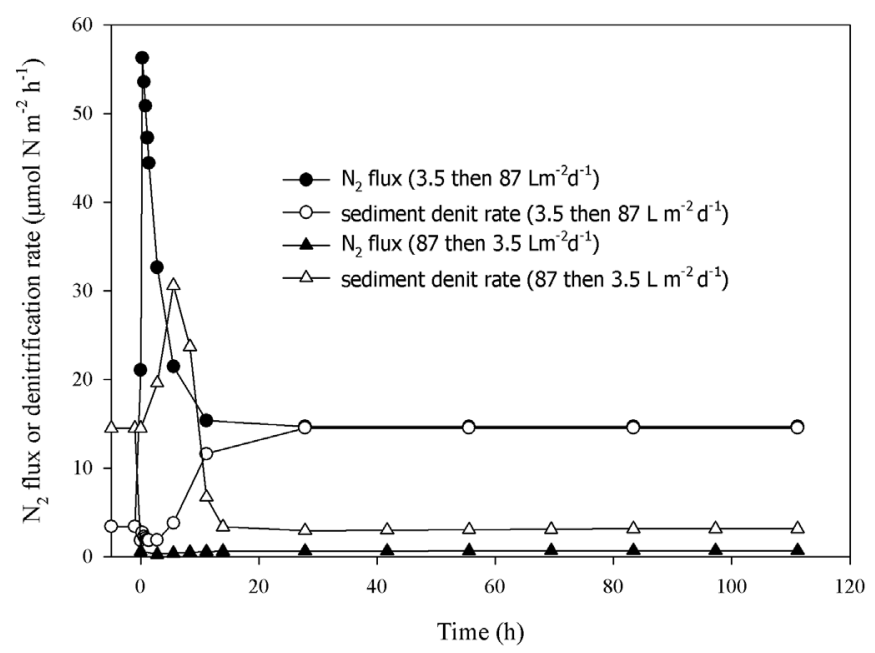

Fig. 4. The initial steady state fluxes of $\mathrm{N}_{2}$ and denitrification (at $t<0$ ), followed by a simulated time-dependent response of sediment denitrification rate and $\mathrm{N}_{2}$ flux out of the sediment after changes in the sediment flushing rate (at $t=0$ ) from 87 and $3.5 \mathrm{~L} \mathrm{~m}^{-2} \mathrm{~d}^{-1}$ and vice versa from 3.5 to $87 \mathrm{~L} \mathrm{~m}^{-2} \mathrm{~d}^{-1}$ with a constant $\mathrm{NO}_{3}{ }^{-}$concentration of $10 \mu \mathrm{mol} \mathrm{\textrm {L } ^ { - 1 }}$ in the water column.

IPT simulation results-Simulated rates of $D_{14}$ took at least 10 $\mathrm{h}$ to come to steady state at a sediment flushing rate of $18 \mathrm{~L} \mathrm{~m}^{-2}$ $\mathrm{d}^{-1}$ for ${ }^{14} \mathrm{NO}_{3}{ }^{-}$concentrations between 0 and $50 \mu \mathrm{mol} \mathrm{L} \mathrm{L}^{-1}$ with a $20 \mu \mathrm{mol} \mathrm{L} \mathrm{L}^{-1}$ addition of ${ }^{15} \mathrm{NO}_{3}{ }^{-}$(Fig. 5a). At a ${ }^{14} \mathrm{NO}_{3}{ }^{-}$concentration of $250 \mu \mathrm{mol} \mathrm{L}{ }^{-1}$ with a $50 \mu \mathrm{mol} \mathrm{L}{ }^{-1}$ addition of ${ }^{15} \mathrm{NO}_{3}^{-}, D_{14}$ took $\sim 20 \mathrm{~h}$ to reach steady state (Fig. 5b). The sediment flushing rate also had an effect on the equilibration time for $D_{14}$ with equilibration times ranging between 10 hour at a flushing rate of $3.5 \mathrm{~L} \mathrm{~m}^{-2} \mathrm{~d}^{-1}$ to $\sim 24$ hour at flushing rates in excess of $44 \mathrm{~L} \mathrm{~m}^{-2} \mathrm{~d}^{-1}$. Under diffusive conditions, the ${ }^{15} \mathrm{NO}_{3}{ }^{-}$came to steady state much more rapidly, with close to steady state conditions for $D_{14}$ being reached within $6 \mathrm{~h}$ of the ${ }^{15} \mathrm{NO}_{3}{ }^{-}$tracer addition. This is still relatively slow compared to that obtained experimentally in muddy and fine sandy sediments (Lohse et al. 1996; Nielsen 1992) and can be explained by the relatively shallow $\mathrm{O}_{2}$ penetration depths in those sediments ( 1 to $2 \mathrm{~mm}$ ) compared to that in the sediment modeled here ( $\sim 4$ to $5 \mathrm{~mm}$ ).

Measured and simulated stirring gradient experiments $-\mathrm{O}_{2}$ fluxes into the sediment increased over the flushing gradient from $250 \mu \mathrm{mol} \mathrm{m}{ }^{-2} \mathrm{~h}^{-1}$ at a sediment flushing rate of $3.7 \mathrm{~L}$ $\mathrm{m}^{-2} \mathrm{~d}^{-1}$ up to $800 \mu \mathrm{mol} \mathrm{m} \mathrm{m}^{-2} \mathrm{~h}^{-1}$ at a sediment flushing rate of $\sim 90 \mathrm{~L} \mathrm{~m}^{-2} \mathrm{~d}^{-1}$ (Fig. 6). Anomalously high $\mathrm{O}_{2}$ fluxes were observed in one core at a flushing rate of $15 \mathrm{~L} \mathrm{~m}^{-2} \mathrm{~d}^{-1}$, most likely due to the presence of macroalgal debris (with a strongly sulfidic smell) observed within the sediment after the incubations concluded. Modeled rates were always lower than direct measurements (Fig. 6), however, the increase in the modeled sediment $\mathrm{O}_{2}$ flux with increased flushing was close to that measured.

There was a delay of $5 \mathrm{~h}$ before any measurable increase in the ${ }^{29} \mathrm{~N}_{2}$ and ${ }^{30} \mathrm{~N}_{2}$ pools could be detected, after which both 

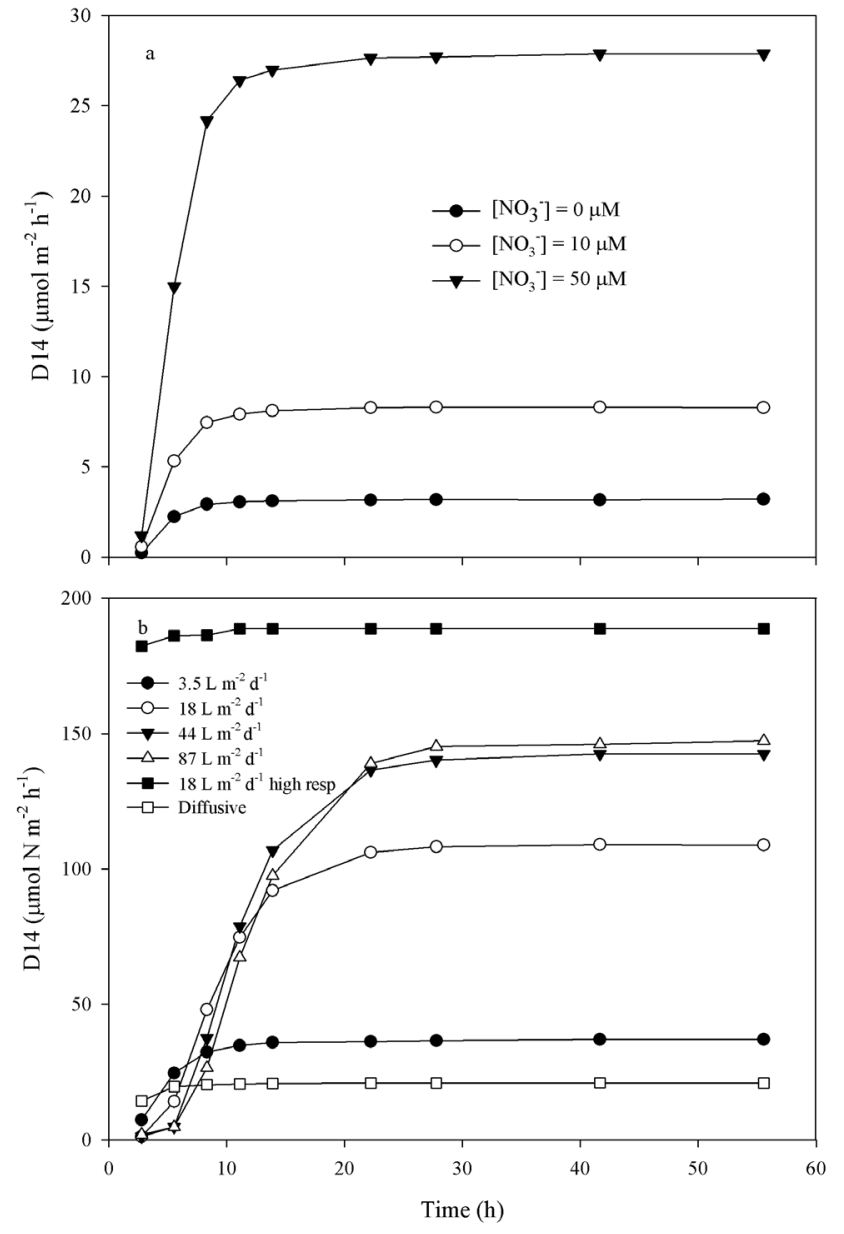

Fig. 5. (a) The simulated development of $D_{14}$ over time after the addition of $20 \mu \mathrm{mol} \mathrm{L}{ }^{-1}{ }^{15} \mathrm{NO}_{3}{ }^{-}$to the water column of cores at steady state with 0,10 , and $50 \mu \mathrm{mol} \mathrm{L}{ }^{-1}{ }^{14} \mathrm{NO}_{3}^{-}$, respectively. (b) The simulated development of $D_{14}$ after the addition of $50 \mu \mathrm{mol} \mathrm{L}^{-1}{ }^{15} \mathrm{NO}_{3}^{-}$to the water column of cores with $250 \mu \mathrm{mol} \mathrm{L}^{-1}{ }^{14} \mathrm{NO}_{3}{ }^{-}$incubated at flushing rates of 3.5 to $87 \mathrm{~L} \mathrm{~m}^{-2} \mathrm{~d}^{-1}$, simulating the incubation conditions of the experimental cores. Also shown is the development of $D_{14}$ under diffusive as well as high respiration conditions at a sediment flushing rate of $18 \mathrm{~L} \mathrm{~m}^{-2} \mathrm{~d}^{-1}$ starting from steady state with $250 \mu \mathrm{mol} \mathrm{L}^{-1}{ }^{14} \mathrm{NO}_{3}^{-}$in the water column.

pools increased rapidly. The modeled increase in the ${ }^{29} \mathrm{~N}_{2}$ and ${ }^{30} \mathrm{~N}_{2}$ pools showed a similar pattern to that measured, with a significant increase in the pools only occurring after $4 \mathrm{~h}$, after which concentrations increased rapidly (Fig. 7a).

$\mathrm{N}_{2}$ fluxes measured using the $\mathrm{N}_{2}$ :Ar method showed a clear increase at increased core stirring speeds with $\mathrm{N}_{2}$ fluxes increasing from $\sim 70$ to $\sim 130 \mu \mathrm{mol} \mathrm{m}^{-2} \mathrm{~h}^{-1}$ (average of both HPL and SCU data sets) when the sediment flushing rate increased from $\sim 3.5$ up to $\sim 90 \mathrm{~L} \mathrm{~m}^{-2} \mathrm{~d}^{-1}$ (Fig. $7 \mathrm{~b}$ ). The "killed control cores" had an average $\mathrm{N}_{2}$ flux of $-0.5 \pm 11$ $\mu \mathrm{mol} \mathrm{m}{ }^{-2} \mathrm{~h}^{-1}$. The modeled $\mathrm{N}_{2}$ fluxes generally agreed well with the measured $\mathrm{N}_{2}$ fluxes, with the exception of the fluxes modeled at a flushing rate of $3.5 \mathrm{~L} \mathrm{~m}^{-2} \mathrm{~d}^{-1}$, which were lower $\left(18 \mu \mathrm{mol} \mathrm{m}^{-2} \mathrm{~h}^{-1}\right)$ than the lowest measured flux $\left(48 \mu \mathrm{mol} \mathrm{m}{ }^{-2} \mathrm{~h}^{-1}\right)$. Interestingly, modeled rates of denitrifi-

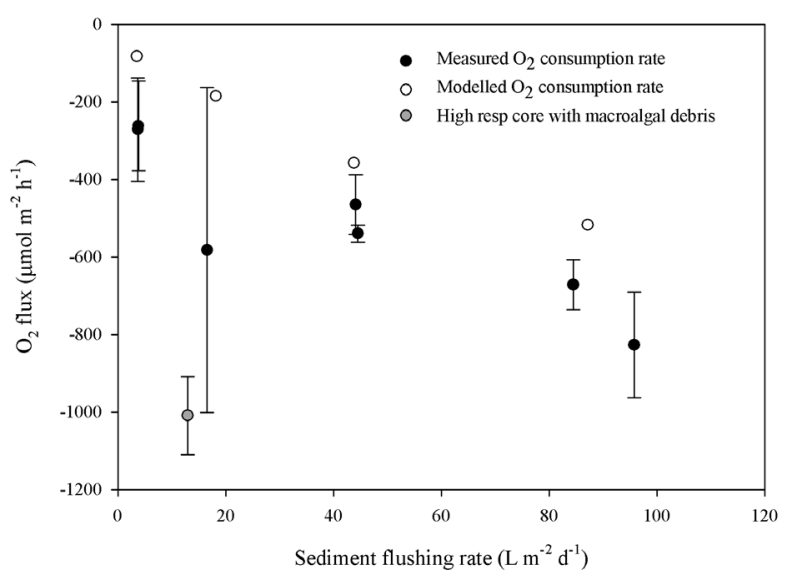

Fig. 6. The measured and simulated sediment $\mathrm{O}_{2}$ fluxes at different sediment flushing rates.

cation increased very little once a flushing rate of $\sim 40 \mathrm{~L} \mathrm{~m}^{-2}$ $\mathrm{d}^{-1}$ was reached.

Rates of denitrification measured using IPT after $11 \mathrm{~h}$ of incubation in the flushing gradient experiments were less than $30 \mu \mathrm{mol} \mathrm{m}{ }^{-2} \mathrm{~h}^{-1}$ and were generally less than $30 \%$ of the rates measured using the $\mathrm{N}_{2}$ :Ar ratios (Fig. $7 \mathrm{~b}$ ). This was with the exception of one data point, measured at a flushing rate of $18 \mathrm{~L}$ $\mathrm{m}^{-2} \mathrm{~d}^{-1}$, which agreed well with the measured rates of denitrification using the $\mathrm{N}_{2}$ :Ar method, and occurred in the core, which had high rates of respiration $\left(\sim-1000 \mu \mathrm{mol} \mathrm{m}^{-2} \mathrm{~h}^{-1}\right)$. Modeled and measured rated of $D_{14}$ after $11 \mathrm{~h}$ incubation were generally in good agreement with the measured rates after $11 \mathrm{~h}$ (Fig. 7b). After a simulated $22 \mathrm{~h}$ pre-incubation, the modeled rates of $D_{14}$, were in close agreement with the modeled denitrification rate.

Bag incubations-The bag incubation experiments showed a close agreement between the rates of denitrification measured using isotopes and the $\mathrm{N}_{2}$ :Ar methods (Table 3), and the rates measured using both methods were highly correlated $\left(r^{2}=0.99\right)$. Denitrification rates increased with increasing $\mathrm{NO}_{3}^{-}$ addition, and a monod kinetic fit to the data pooled for both methods yielded a of $30 \mu \mathrm{mol} \mathrm{L}{ }^{-1}$ and a maximum rate constant of $270 \mathrm{nmol} \mathrm{N} \mathrm{mL} \mathrm{sed}{ }^{-1} \mathrm{~d}^{-1}\left(r^{2}=0.83\right)$. Organic matter additions apparently had no effect on the rate of denitrification under the given conditions.

$\mathrm{N}_{2}$ :Ar laboratory comparison-There was a significant offset of $\sim 10 \mu \mathrm{mol} \mathrm{L}^{-1}$ in the $\mathrm{N}_{2}$ concentrations measured by SCU and HPL (data not shown). Despite the consistent offset in concentrations of $\mathrm{N}_{2}$, there was no consistent offset between the rates obtained from both instruments (paired $t$ test, $P>>$ 0.1 . There were, however, large discrepancies at times, with the rates differing by up to $60 \%$ of the mean, the average difference between the rates was $\pm 37 \%$ of the mean. There was no correlation $\left(r^{2}=0.02\right)$ between the rates calculated from the data obtained from the two labs. Thus, whereas the data from both labs showed no co-variation, no systematic differences in the rates obtained from each lab could be distinguished. As 

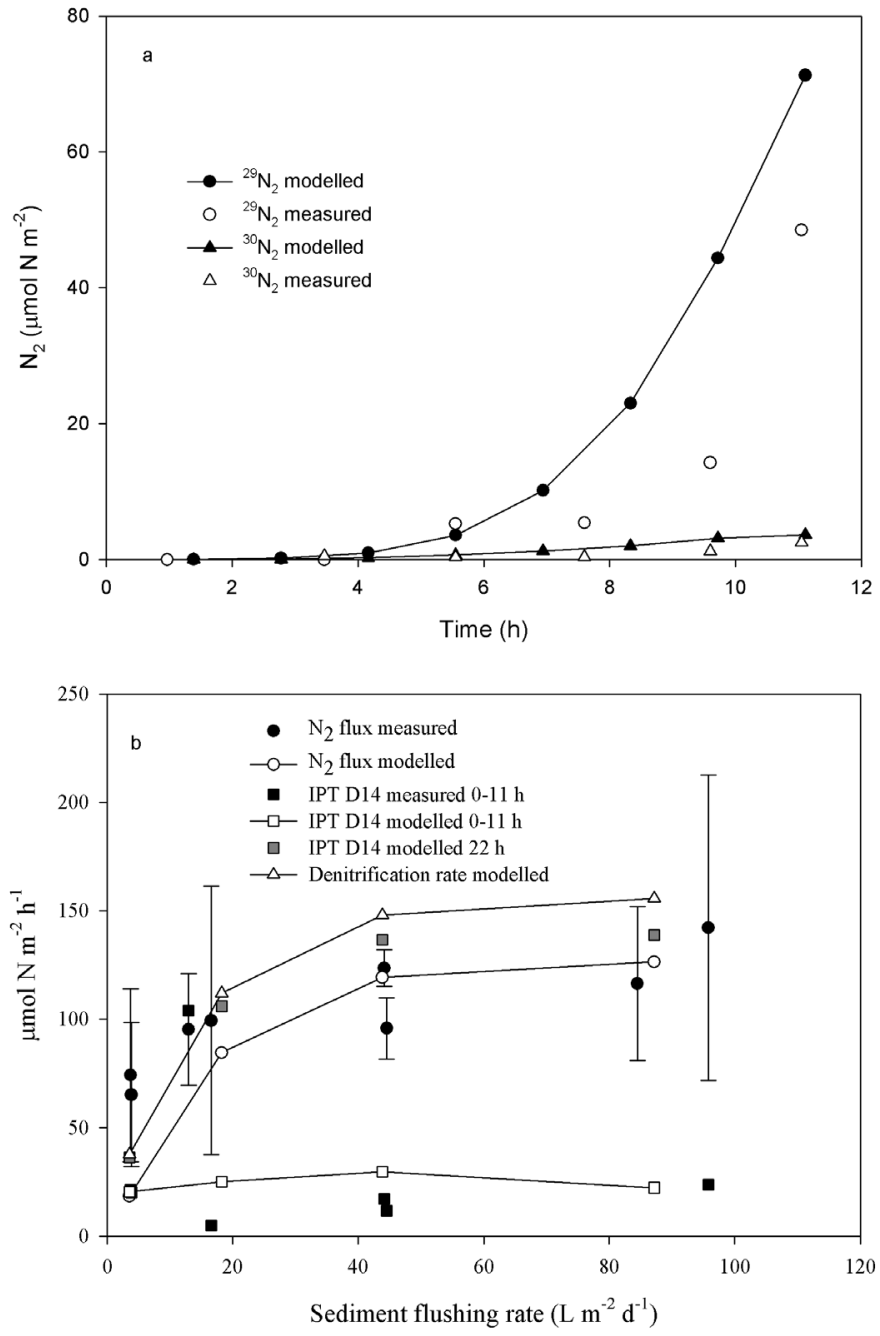

Fig. 7. (a) The modeled and measured time-dependent amounts of ${ }^{29} \mathrm{~N}_{2}$ and ${ }^{30} \mathrm{~N}_{2}$ after the addition of $50 \mu \mathrm{mol} \mathrm{L} \mathrm{L}^{-1}{ }^{15} \mathrm{NO}_{3}{ }^{-}$to a water column con-

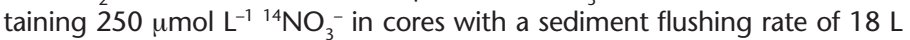
$\mathrm{m}^{-2} \mathrm{~d}^{-1}$. (b) Modeled and measured $\mathrm{N}_{2}$ fluxes or denitrification rates at sediment flushing rates in cores ranging from $\sim 3.5$ to $\sim 90 \mathrm{~L} \mathrm{~m}^{-2} \mathrm{~d}^{-1}$. Measured data shown are $\mathrm{N}_{2}$ fluxes (data from both laboratories, mean \pm range, $n=$ 2, filled circles) and IPT after an 11-h incubation (filled squares). Modeled data shown are $\mathrm{N}_{2}$ fluxes (open circles), rates of denitrification (open triangles), $D_{14}$ simulating an incubation period of 0 to $11 \mathrm{~h}$ (open squares) and $D_{14}$ simulated $42 \mathrm{~h}$ after label addition (gray squares). Note the high rate of $D_{14}$ measured after an 11-h incubation for the core with a flushing rate of $\sim 15 \mathrm{~L} \mathrm{~m}^{-2} \mathrm{~d}^{-1}$ which was the same core with high respiration rates remarked upon in Figure 6. (see Discussion for explanation).

such, the removal of $\mathrm{O}_{2}$ in the mass spectrometer did not appear to have a significant impact on the measured $\mathrm{N}_{2}$ fluxes. The observations also underline the importance of careful handling of $\mathrm{N}_{2}$ :Ar samples prior to analysis and the need for short storage times. Although no bubbles were observed in our samples immediately before analysis, the conditions were not optimal in the present investigation, with long transport distances and storage times of several weeks under poorly controlled temperatures (no bubble formation was observed). The
Table 3. Volumetric rates of denitrification measured using isotope production and the $\mathrm{N}_{2}$ :Ar method in bag incubations of sediment from the study site for different treatments

\begin{tabular}{|c|c|c|}
\hline Treatment & Isotopes & $\mathrm{N}_{2}: \mathrm{Ar}$ \\
\hline $20 \mu \mathrm{mol} \mathrm{L}-1{ }^{15} \mathrm{NO}_{3}^{-}$ & $97 \pm 2$ & $134 \pm 15$ \\
\hline $50 \mu \mathrm{mol} \mathrm{L}{ }^{-1}{ }^{15} \mathrm{NO}_{3}^{-}$ & $130 \pm 6$ & $164 \pm 29$ \\
\hline $100 \mu \mathrm{mol} \mathrm{L}-15 \mathrm{NO}_{3}^{-}$ & $201 \pm 3$ & $227 \pm 23$ \\
\hline $20 \mu \mathrm{mol} \mathrm{L}{ }^{-1}{ }^{15} \mathrm{NO}_{3}^{-}+0.1 \mathrm{~g} \mathrm{bag}^{-1}$ Spirulina & $87 \pm 5$ & $132 \pm 17$ \\
\hline $100 \mu \mathrm{mol} \mathrm{L}{ }^{-1}{ }^{15} \mathrm{NO}_{3}^{-}+0.1 \mathrm{~g} \mathrm{bag}^{-1}$ Spirulina & $200 \pm 6$ & $213 \pm 17$ \\
\hline
\end{tabular}

Values shown are $\mathrm{nmol} \mathrm{N} \mathrm{mL} \mathrm{sed}{ }^{-1} \mathrm{~d}^{-1} \pm$ standard error of the regression.

observation may also suggest the need for intercalibration between different instruments.

\section{Discussion}

Model comparison with measured data-The close agreement between the rates of denitrification measured using isotopes and the $\mathrm{N}_{2}$ :Ar method in the bag incubations (Table 3) confirmed that the discrepancies observed between the two methods in the core incubations did not arise from analytical errors. Thus, the discrepancies observed were most likely related to transport phenomena as discussed below.

The modeled $\mathrm{O}_{2}$ fluxes were consistently slightly lower than those measured in the cores (Fig. 6). This discrepancy most likely arises from the fact that we only included diffusion and an advective flow field generated from the pressure gradients within the cores in the model. In reality, additional transport through bioturbation (also referred to as enhanced diffusion for solutes), bioirrigation, and possibly also small scale advective flushing of the top few millimeters of sediment will occur. Additionally macrofauna themselves (which were deliberately excluded from the bag incubations) will also consume $\mathrm{O}_{2}$. These additional transport and consumption mechanisms will mean that $\mathrm{O}_{2}$ consumption rates within the cores will be higher than that modeled. Despite the slight offset in the absolute rates, however, there was a good agreement between increase in the sediment $\mathrm{O}_{2}$ consumption rates for the modeled and measured data, which gives us confidence that the advective component of transport driven by pressure gradients within the core was well parameterized in our model. Because the aforementioned transport processes decrease exponentially with depth (e.g., Berg et al. 2003), they are likely to have much less impact on the modeled denitrification rates than the $\mathrm{O}_{2}$ fluxes since denitrification only occurs below the oxic zone of the sediment. Indeed, there was no consistent offset between the modeled and measured rates of denitrification (Fig. 7b).

Both the experimental and modeling approaches clearly showed that the production of labeled $\mathrm{N}_{2}$ will not come to steady state until 6 to $24 \mathrm{~h}$ after the ${ }^{15} \mathrm{NO}_{3}{ }^{-}$tracer addition in permeable sediments with advective flushing. Thus, the rates of denitrification measured using IPT will underestimate denitrification rates in sandy sediments when the incubation is commenced immediately after ${ }^{15} \mathrm{NO}_{3}{ }^{-}$addition, as was the case 

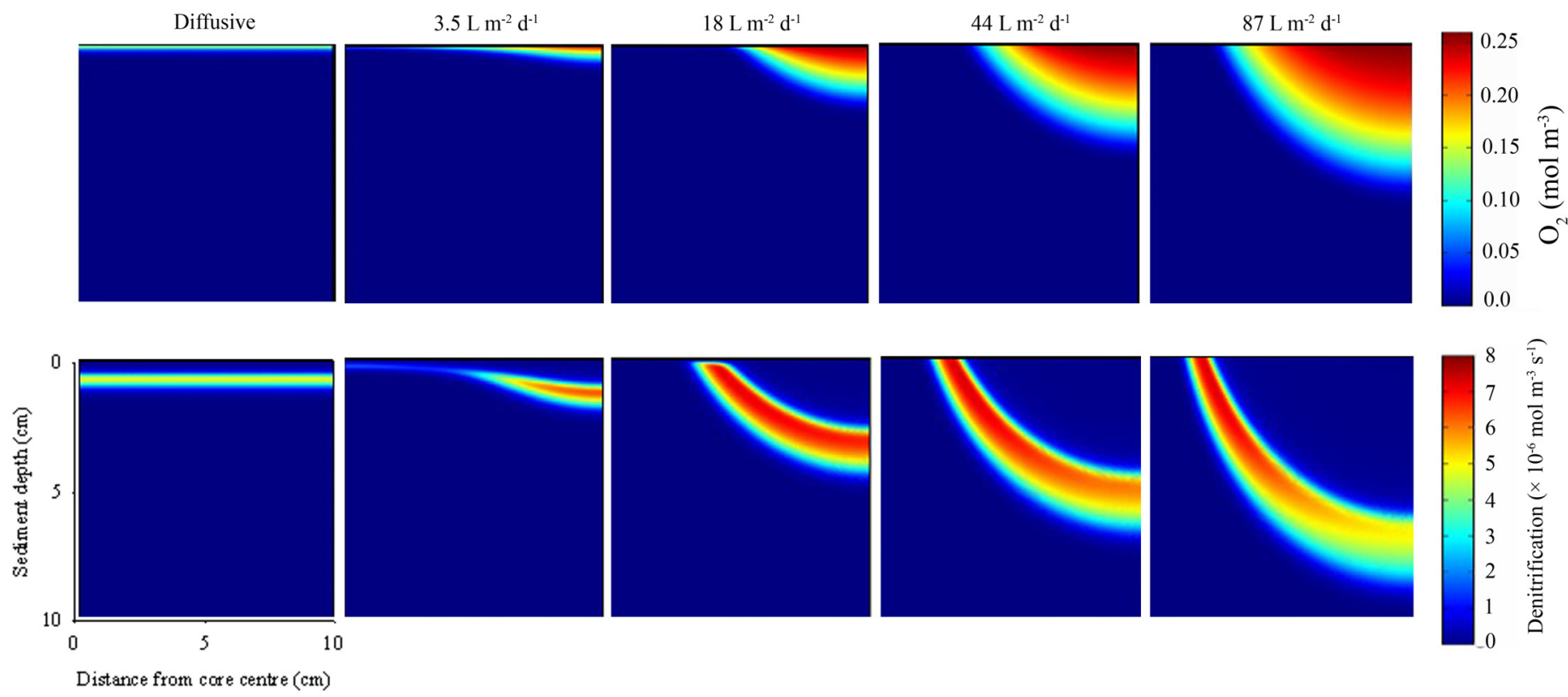

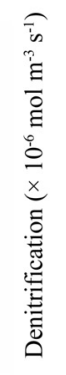

Fig. 8. The simulated effect of sediment flushing rate on the $\mathrm{O}_{2}$ distribution within the sediment (top panels) and the distribution of denitrification within the sediment (bottom panels) in an axial slice (as illustrated in Fig. 1c) of the upper portion of the core with a water column $\mathrm{NO}_{3}^{-}$concentration of 250 umol $\mathrm{L}^{-1}$.

here. This is in contrast to most reports of IPT incubations for sediments with low permeability in the literature, which show that the production of labeled $\mathrm{N}_{2}$ reaches steady state within $1 \mathrm{~h}$ of tracer addition (e.g., Nielsen 1992; Rysgaard et al. 1995).

As mentioned in the Methods section, a true simulation of the $\mathrm{N}_{2}$ fluxes for our core incubations was not possible because we didn't know the initial $\mathrm{N}_{2}$ distribution within the sediment. Thus, we assumed that the $\mathrm{N}_{2}$ distribution within the cores was at steady state at each flushing rate simulated prior to the addition of $250 \mu \mathrm{M} \mathrm{NO}_{3}{ }^{-}$to the water bath. Evidence for the validity of this simplified approach comes from the fact that there was an insignificant flux of $\mathrm{N}_{2}$ out of the sediment in the killed control cores, suggesting there was no major re-equilibration of the sediment $\mathrm{N}_{2}$ pool. The modeled data generally fell within the range of the measured data and also followed the same trend (Fig. 7b). However, the modeled $\mathrm{N}_{2}$ flux was slightly lower than the measured data at flushing rates of $\sim 3.5 \mathrm{~L} \mathrm{~m}^{-2} \mathrm{~d}^{-1}$. Such differences may be related to inaccurately estimated rates and distribution of $\mathrm{R}_{\min }$ (the rate constant for organic matter mineralisation within the sediment), differences between the actual and modeled initial $\mathrm{N}_{2}$ distribution within the sediment when the cores were collected from the field, additional transport phenomena to those included in the model and different sediment permeability.

A major discrepancy between the modeled and measured denitrification rates was observed in the core run at a sediment flushing rate of $\sim 15 \mathrm{~L} \mathrm{~m}^{-2} \mathrm{~d}^{-1}$ (Fig. 7b), where it can be seen that the observed $D_{14}$ was much higher than that modeled. This outlying core was the one with a high rate of sediment respiration noted in Fig. 6. Our simulations showed that increased sediment respiration greatly reduced the time for $D_{14}$ to come to steady state after ${ }^{15} \mathrm{NO}_{3}{ }^{-}$addition (Fig. $5 \mathrm{~b}$ ), thus explaining the much higher rate of $D_{14}$ measured after $11 \mathrm{~h}$ in this core compared to the other lower respiration cores.

Effect of flushing on the sediment denitrification rate and methodological implications-Before discussing the methodological implications of our findings we would like to stress that the absolute values of our results are only applicable to the experimental and modeled core geometry used here. Rates and equilibration times will vary between experimental geometries. Nevertheless, our data clearly show the impact of advective porewater exchange on denitrification and the following discussion provides an insight into the types of interactions that might be expected.

The overall effect of sediment flushing versus diffusive conditions on denitrification had a strong dependence on the $\mathrm{NO}_{3}{ }^{-}$concentration in the water column. Under diffusive conditions, the model simulations suggested a much greater nitrification rate and, hence, denitrification fed from nitrification (Fig. 2a). As such, when no $\mathrm{NO}_{3}{ }^{-}$was present in the water column (that is, $100 \%$ coupled nitrification/denitrification), denitrification rates were approximately 2 to 6 times higher under diffusive compared to flushed conditions. With the onset of flushing, nitrification initially decreased markedly (Fig. 2b) because reduced substances such as $\mathrm{NH}_{4}^{+}$, can leave the sediment without passing through an oxic zone in the sediment (Fig. 8), in agreement with experimental observations (Huettel et al. 1998). At increased sediment flushing rates, nitrification did increase again slightly (Fig. 2b) as the oxic zone of the sediment expanded (Fig. 8). At higher $\mathrm{NO}_{3}{ }^{-}$concentrations in the water column, sediment flushing led to higher denitrification rates than under diffusive conditions, enhancing denitrification by factors of up to $\sim 5$. This results from an increased area across which $\mathrm{NO}_{3}{ }^{-}$can enter the denitrification zone and also 
increased $\mathrm{NO}_{3}^{-}$transport rates into the anoxic zone, which together result in a greater sediment volume with potential denitrification (Fig. 8). The size of the oxic/anoxic interface only increases marginally above a flushing rate of 18 to $44 \mathrm{~L}$ $\mathrm{m}^{-2} \mathrm{~d}^{-1}$ at the sediment respiration rates used and, therefore, the sediment denitrification rate only increases marginally above this rate. The effect of flushing on denitrification, thus, is a complex interaction between nitrification rates, $\mathrm{NO}_{3}{ }^{-}$water column concentrations, pore water flow fields, and sediment respiration rates. As such, the potential effect of flushing should be considered with regard to the field site or experimental system in question.

Our results highlight the importance of considering advective processes when performing denitrification measurements (or any other process rate) in sandy sediments. To date, all published studies of denitrification in sandy sediments have been conducted in small diameter cores (e.g., Jensen et al. 1996; Lohse et al. 1996), with no consideration given to advective processes. It is possible that the circular stirring mechanisms employed in such incubations may have led to a certain amount of advective pore water circulation within the cores (although we note in the study of Lohse et al. 1996, this was purposely avoided by switching the stirring direction at $5 \mathrm{~s}$ intervals). However, it is most likely that the advective flushing rates in such narrow core incubations are low. Therefore, we suggest that studies of denitrification in sandy sediments, which do not take into account advective processes may underestimate the process by several times when $\mathrm{NO}_{3}^{-}$water concentrations are low, or possibly overestimate the rates when sediment $\mathrm{NH}_{4}{ }^{+}$concentrations are high. We, therefore, suggest that simple modeling approaches, such as the one used here, be used to predict the impact of sediment flushing rates on denitrification rates and that such models be used to design representative experiments in permeable sandy sediments.

The experimental and modeling studies performed here highlight the shortcomings of both IPT and direct $\mathrm{N}_{2}$ flux measurements in sandy sediments under advective flow fields. IPT requires a long time after ${ }^{15} \mathrm{NO}_{3}{ }^{-}$tracer addition to reach steady state (up to $24 \mathrm{~h}$ ), stressing the need for experimental studies to add the ${ }^{15} \mathrm{NO}_{3}{ }^{-}$tracer $\sim 1 \mathrm{~d}$ in advance before a time series measurement of $\mathrm{N}_{2}$ production is commenced. Aside from this shortcoming, IPT has the advantage that once the ${ }^{15} \mathrm{NO}_{3}{ }^{-}$tracer has reached steady state within the sediment, the production of labeled $\mathrm{N}_{2}$ gas gives a true measure of denitrification rate (assuming no anammox) occurring under the current incubation conditions.

The flux of $\mathrm{N}_{2}$ across SWI will only reflect the actual denitrification rate under steady state conditions. When large perturbations to steady state conditions are made, such as the addition of $\mathrm{NO}_{3}{ }^{-}$to a core, the $\mathrm{N}_{2}$ flux across SWI will take well in excess of $5 \mathrm{~d}$ to reach steady state with the newly established denitrification rates (Fig. 3). This finding agrees with that of Jahnke et al. (2000), who suggested that changed rates of pore water transport resulting from chamber emplacement would lead to measured fluxes of nutrients being out of balance with production rates for weeks to months. As such, $\mathrm{N}_{2}$ fluxes must be integrated over appropriate time scales when using this technique in sediments that experience variable $\mathrm{NO}_{3}^{-}$ and $\mathrm{NH}_{4}{ }^{+}$concentrations in the water column. In addition, the direct flux of $\mathrm{N}_{2}$ across SWI is highly sensitive to changes in sediment flushing rates (Fig. 4). An increase in the sediment flushing rate from a previous condition of lower flushing will result in a "washout" of $\mathrm{N}_{2}$ previously accumulated in the pore water, leading to erroneously high measurements of denitrification. Similarly a reduction in the flushing rate will lead to an underestimate in denitrification rates, because the $\mathrm{N}_{2}$ concentrations in the pore water are lower than would be expected at steady state for the newly established transport regime. This finding has important implications for benthic chamber studies in permeable sediments, where flux measurements are commenced shortly after chamber emplacement, which establishes a new sediment flushing regime. The model simulations suggest that artefacts occurring from changes in the flushing conditions are relatively short and most likely would not produce significant experimental artefacts if the newly imposed flushing state is allowed to "equilibrate" for $\sim 24 \mathrm{~h}$.

Given the aforementioned disadvantages of core and chamber incubations, we suggest that the organic matter mineralisation rate $\left(\mathrm{R}_{\min }\right.$, both as $\mathrm{C}$ and $\mathrm{N}$ equivalents) and the nitrification rates $\left(k_{\mathrm{NI}}\right)$ be measured within the surface layers of the sediment under consideration. These parameters can then be used in conjunction with a range of sediment flushing rates to reconstruct the likely rates of denitrification under a range of conditions likely to be encountered in-situ. In terms of the experimental approach to determine these kinetic parameters, we suggest the use of short intact sediment columns where the substrates are pumped through under oxic or anoxic conditions. By taking such an approach, the structural integrity of the sand and the mode of substrate delivery are maintained. Additonally, the above-mentioned problems of non-steady state conditions are overcome. Furthermore, this approach avoids the use of the large "advective" sediment cores described here, which are cumbersome and impractical in deep water sites. The present work clearly emphasizes the complexity for resolving in situ process rates in coastal sandy sediments, where environmental controls such as flow velocities, temperature, salinity, and nutrient concentrations are constantly changing; a dynamic poorly represented by traditional chamber enclosures.

\section{Comments and recommendations}

We identified a number of factors that should be considered when measuring denitrification in permeable sediments. First, sediment flushing may significantly affect rates of denitrification, which calls into question rate measurements made in small diameter intact cores that do not reproduce advective processes likely to occur in the field. Second, we identified a 
number of methodological considerations pertinent to direct $\mathrm{N}_{2}$ flux measurements and IPT. Changes in sediment flushing rates and water column $\mathrm{NO}_{3}{ }^{-}$concentrations will lead to a transient offset in $\mathrm{N}_{2}$ fluxes compared to actual denitrification rates within the sediment until a new steady state is reached. The time needed for equilibration to the new steady state may be 1 to $5 \mathrm{~d}$ depending on the nature of the perturbation. The measurement of denitrification using IPT in stirred cores with a radius of $95 \mathrm{~mm}$ require pre-incubations of $\sim 24 \mathrm{~h}$ after ${ }^{15} \mathrm{NO}_{3}{ }^{-}$addition before a steady-state production of labeled $\mathrm{N}_{2}$ will occur. As such, if core incubations are to be used to measure denitrification in sandy sediments, they should be set up to mimic advective processes and have pre-incubation times for longer than $1 \mathrm{~d}$ to allow a re-equilibration of the $\mathrm{N}_{2}$ pool within the sediment associated with changed flushing conditions. Long pre-incubation times may also be necessary at sites that experience large changes in $\mathrm{NO}_{3}{ }^{-}$concentrations in the water column and sediments, due to, for example, the mixing of two water bodies and or the activity of benthic microphytes. Because the rates of denitrification are affected by the sediment flushing rate, we suggest that, ideally, parameters such as the saturation and half saturation constants of the denitrification rate and sediment respiration rates be determined for the particular sediment and that this be used in conjunction with knowledge of sediment flushing rates to model in-situ denitrification rates.

\section{References}

Bear, J., and Y. Bachmat. 1991. Introduction to modeling of transport phenomena in porous media. Kluwer.

Berg, P., S. Rysgaard, and B. Thamdrup. 2003. Dynamic modeling of early diagenesis and nutrient cycling. A case study in an Arctic marine sediment. Am J Sci 303:905-955.

Boudreau, B. P. 1996. The diffusive tortuosity of fine-grained unlithified sediments. Geochim Cosmochim Acta 60: 3139-3142.

1997a. Diagenetic models and their implementation, 1st ed. Springer Verlag.

Cook, P. L. M., A. T. Revill, B. D. Eyre, and E. C. V. Butler. 2004. Benthic carbon and nitrogen cycling on intertidal mudflats of a temperate Australian estuary II. Nitrogen cycling. Mar Ecol Prog Ser 280:39-54.

Dalsgaard, T., and others. 2000. Protocol handbook for NICEnitrogen cycling in Estuaries: a project under the EU research programme: Marine Science and Technology (MAST III). National Environmental Research Inst.

Emery, K. O. 1968. Relict sediments on continental shelves of the world. Am Assoc Petrol Geo Bull 52:445-464.

Eyre, B. D., and A. J. P. Ferguson. 2002. Comparison of carbon production and decomposition, benthic nutrient fluxes and denitrification in seagrass, phytoplankton, benthic microalgae- and macroalgae-dominated warm-temperate Australian lagoons. Mar Ecol Prog Ser 229:43-59.

Eyre, B. D., S. Rysgaard, T. Dalsgaard, and P. B. Christensen.
2002. Comparison of isotope pairing and $\mathrm{N}_{2} / \mathrm{Ar}$ methods for measuring sediment denitrification-assumptions, modifications and implications. Estuaries 25:1077-1087.

Freeze, R. A., and J. A. Cherry. 1979. Groundwater. Prentice Hall. Glud, R. N., S. Forster, and M. Huettel. 1996. Influence of radial pressure gradients on solute exchange in stirred benthic chambers. Mar Ecol Prog Ser 141:303-311.

Grasshoff, K. 1983. Methods of seawater analysis, 2nd ed. Verlag Chemie.

Huettel, M., and G. Gust. 1992. Solute release mechanisms from confined sediment cores in stirred benthic chambers and flume flows. Mar Ecol Prog Ser 82:187-197.

Huettel, M., H. Roy, E. Precht, and S. Ehrenhauss. 2003. Hydrodynamical impact on biogeochemical processes in aquatic sediments. Hydrobiologia 494:231-236.

Huettel, M., W. Ziebis, S. Forster, and G. W. Luther. 1998. Advective transport affecting metal and nutrient distributions and interfacial fluxes in permeable sediments. Geochim Cosmochim Acta 62:613-631.

Jahnke, R. A., J. R. Nelson, R. L. Marinelli, and J. E. Eckman. 2000. Benthic flux of biogenic elements on the Southeastern US continental shelf: influence of pore water advective transport and benthic microalgae. Cont Shelf Res 20:109-127.

Janssen, F., P. Faerber, M. Huettel, V. Meyer, and U. Witte. 2005a. Pore-water advection and solute fluxes in permeable marine sediments (I): Calibration and performance of the novel benthic chamber system Sandy. Limnol Oceanogr 50: 786-778.

Janssen, F., M. Huettel, and U. Witte. 2005b. Pore-water advection and solute fluxes in permeable marine sediments (II): Benthic respiration at three sandy sites with different permeabilities. Limnol Oceanogr 50:779-772.

Jensen, K. M., M. H. Jensen, and E. Kristensen. 1996. Nitrification and denitrification in Wadden Sea sediments (Konigshafen, Island of Sylt, Germany) as measured by nitrogen isotope pairing and isotope dilution. Aquat Microbial Ecol 11:181-191.

Kana, T. M., C. Darkangelo, M. D. Hunt, J. B. Oldham, G. E. Bennett, and J. C. Cornwell. 1994. Membrane inlet mass spectrometer for rapid high precision determination of $\mathrm{N}_{2}, \mathrm{O}_{2}$, and Ar in environmental water samples. Anal Chem 66:4166-4170.

Kana, T. M., M. B. Sullivan, J. C. Cornwell, and K. Groszkowski. 1998. Denitrification in estuarine sediments determined by membrane inlet mass spectrometry. Limnol Oceanogr 43:334-339.

Kana, T. M., and D. L. Weiss. 2004. Comment on "Comparison of isotope pairing and N-2 :Ar methods for measuring sediment denitrification." Estuaries 27:173-176.

Klute, A., and C. Dirksen. 1986. Hydraulic conductivity and diffusivity: laboratory methods, p. 687-700. In A. Klute [ed.], Methods of soil analysis. Part 1-Physical and mineralogical methods. American Society of Agronomy.

Lohse, L., H. T. Kloosterhuis, W. vanRaaphorst, and W. Helder. 1996. Denitrification rates as measured by the isotope pair- 
ing method and by the acetylene inhibition technique in continental shelf sediments of the North Sea. Mar Ecol Progr Ser 132:169-179.

Meysman, F. J. R., O. S. Galaktionov, B. Gribsholt, and J. J. Middelburg. 2006. Bio-irrigation in permeable sediments:advective pore water transport induced by burrow ventilation. Limnol Oceanogr 51:142-156.

Meysman, F. J. R., O. S. Galaktionov, and J. J. Middelburg. 2005. Irrigation patterns induced in permeable sediments by burrow ventilation: a case study of Arenicola marina. Mar Ecol Progr Ser 303:195-212.

Meysman, F. J. R., J. J. Middelburg, P. M. J. Herman, and C. H. R. Heip. 2003. Reactive transport in surface sediments. II. Media: an object-oriented problem-solving environment for early diagenesis. Comp Geosci 29: 301-318.

Middelburg, J. J., K. Soetaert, and P. M. J. Herman. 1996. Evaluation of the nitrogen isotope-pairing method for measuring benthic denitrification:a simulation analysis. Limnol Oceanogr 41:1839-1844.

Nielsen, L. P. 1992. Denitrification in sediment determined from nitrogen isotope pairing. FEMS Microbiol Ecol 86:357-362.

Nielsen, L. P., and R. N. Glud. 1996. Denitrification in a coastal sediment measured in situ by the nitrogen isotope pairing technique applied to a benthic flux chamber. Mar Ecol Prog Ser 137:181-186.

Precht, E., U. Franke, L. Polerecky, and M. Huettel. 2004. Oxygen dynamics in permeable sediments with wave-driven porewater exchange. Limnol Oceanogr 49:693-705.

Precht, E., and M. Huettel. 2003. Advective pore-water exchange driven by surface gravity waves and its ecological implications. Limnol Oceanogr 48:1674-1684.

Risgaard Petersen, N., L. P. Nielsen, S. Rysgaard, D. T, and R. L. Meyer. 2003. Application of the isotope pairing technique in sediments where anammox and denitrification coexist. Limnol Oceanogr: Methods 1:63-73.
Risgaard Petersen, N., and S. Rysgaard. 1995. Nitrate reduction in sediments and waterlogged soil measured by ${ }^{15} \mathrm{~N}$ techniques, p. 287-295. In K. Alef and P. Nannipieri [eds.], Methods in applied soil microbiology and biochemistry. Academic Press.

Risgaard Petersen, N., S. Rysgaard, L. P. Nielsen, and N. P. Revsbech. 1994. Diurnal variation of denitrification and nitrification in sediments colonized by benthic microphytes. Limnol Oceanogr 39:573-579.

Rysgaard, S., P. B. Christensen, and L. P. Nielsen. 1995. Seasonal variation in nitrification and denitrification in estuarine sediment colonized by benthic microalgae and bioturbating infauna. Mar Ecol Prog Ser 126:111-121.

Rysgaard, S., R. N. Glud, N. Risgaard-Petersen, and T. Dalsgaard. 2004. Denitrification and anammox activity in Arctic marine sediments. Limnol Oceanogr 49:1493-1502.

Soetaert, K., P. M. J. Herman, and J. J. Middelburg. 1996. A model of early diagenetic processes from the shelf to abyssal depths. Geochim Cosmochim Acta 60:1019-1040.

van Cappellen, P., and Y. Wang. 1996. Cycling of iron and manganese in surface sediments: A general theory for the coupled transport and reaction of carbon, oxygen, nitrogen, sulfur, iron, and manganese. Am J Sci 296: 197-243.

Vance-Harris, C., and E. Ingall. 2005. Denitrification pathways and rates in the sandy sediments of the Georgia continental shelf, USA. Geochem Trans 6:12-18.

Wang, Y. F., and P. Van Cappellan. 1996. A multicomponent reactive transport model of early diagenesis: application to redox cycling in coastal marine sediments. Geochim Cosmochim Acta 60:2993-3014.

Webb, J. E., and J. Theodor. 1968. Irrigation of submerged marine sands through wave action. Nature 220:682-683.

Submitted 21 October 2005

Revised 5 May 2006

Accepted 1 August 2006 